Spring 2014

\title{
What's Wrong with a Federal Inheritance Tax?
}

Wendy G. Gerzog

University of Baltimore School of Law, wgerzog@ubalt.edu

Follow this and additional works at: http://scholarworks.law.ubalt.edu/all_fac

Part of the Estates and Trusts Commons, Taxation-Federal Commons, Taxation-Federal Estate and Gift Commons, and the Tax Law Commons

\section{Recommended Citation}

What's Wrong with a Federal Inheritance Tax?, 49 Real Prop. Tr. \& Est. L.J. 163 (2014-2015)

This Article is brought to you for free and open access by the Faculty Scholarship at ScholarWorks@University of Baltimore School of Law. It has been accepted for inclusion in All Faculty Scholarship by an authorized administrator of ScholarWorks@University of Baltimore School of Law. For more information, please contact snolan@ubalt.edu. 


\title{
WHAT'S WRONG WITH A FEDERAL INHERITANCE TAX?
}

\author{
Wendy C. Gerzog*
}

Synopsis: Scholars have proposed a federal inheritance tax as an alternative to the current federal transfer taxes, but that proposal is seriously flawed. In any inheritance tax model, scholars should expect to see significantly decreased compliance rates and increased administrative costs because, by focusing on the transferees instead of on the transferor, an inheritance tax would multiply the number of taxpayers subject to the tax.

This Article reviews common characteristics of existing inheritance tax systems in the United States and internationally-particularly in Europe. In addition, the Article analyzes the novel Comprehensive Inheritance Tax (CIT) proposal, which combines some elements of existing inheritance tax systems with some features of the current transfer tax system and delivers the CIT through the federal income tax system.

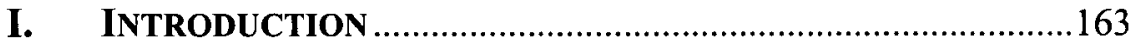

II. EXISTING INHERITANCE TAX SYSTEMS ...........................175

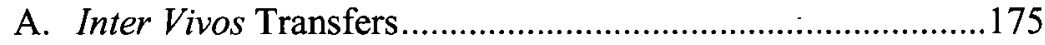

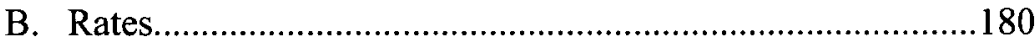

C. Exemptions for Specific Types of Property .........................182

D. Transfers to Charity ..........................................................185

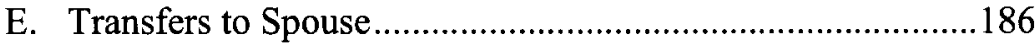

III. THE COMPREHENSIVE INHERITANCE TAX (CIT)

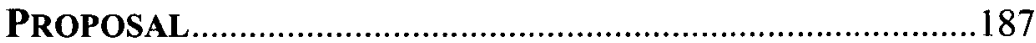

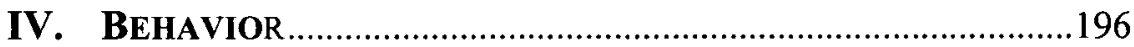

V. WHAT A FEDERAL INHERITANCE TAX OFFERS A TRANSFER

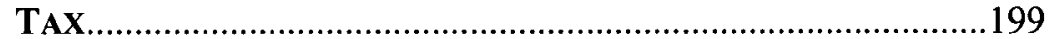

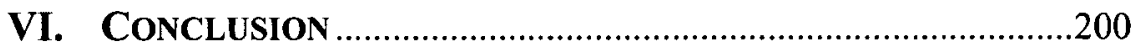

\section{INTRODUCTION}

Periodically, scholars have proposed alternatives to the current federal transfer tax system. ${ }^{1}$ One of those proposals has been for the United States

* Professor, University of Baltimore School of Law. The author wishes to thank Professors Mary Louise Fellows, Anthony Infanti, Kerry Ryan, Jane Schukoske, Theodore Seto, and the participants at the following conferences for their very helpful comments: The Association of American Law Schools' 2012 Annual Meeting in Washington, D.C.; 2012 Critical Tax Conference at Seton Hall Law School; 2013 Law and Society Annual Meeting 
to adopt a federal inheritance tax. In fact, for 4 years the United States had a federal inheritance tax to finance the Spanish American War, but after the war in 1902 the inheritance tax was abolished. ${ }^{2}$ Although positive aspects of an inheritance tax exist, equity and compliance issues ultimately would plague and undermine that alternative tax.

A fundamental problem with existing inheritance tax systems is their basing tax rates on a decedent's relation to a beneficiary. ${ }^{3}$ This emphasis is objectionable on fairness considerations. Why should the familial identity of the beneficiary matter? What public policy concerns are fostered by

in Boston, Massachusetts, Tax Law and Society 12: Taxing Wealth Transfers (session sponsored by the Law, Society, and Taxation Collaborative Research Network). The author also thanks her research assistant, Brooke Shemer, for helping edit this Article.

${ }^{1}$ The federal transfer taxes include the gift, estate, and generation-skipping transfer taxes.

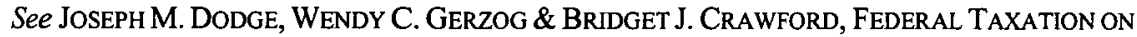
GRATUTTOUS TRANSFERS: LAW AND PLANNING 31-60(2011). See generally Alternatives to the Current Federal Estate Tax System: Hearings Before the S. Comm. on Finance, 110th Cong. 1017 (2008) [hereinafter 2008 Hearings on Alternatives] (statements of Lily Batchelder, Professor, New York University School of Law; Joseph M. Dodge, Professor, Florida State University College of Law; and David Duff, Professor, University of Toronto Faculty of Law). See also id. at 76 (statement of Professor Joseph M. Dodge) ("There are five possible alternatives to the current estate, gift, and generation-skipping system: (1) classic inheritance tax, (2) accessions tax, (3) income-inclusion approach, (4) deemed-realization-at-gift-orbequest-approach, and (5) carryover-basis approach."); Joseph M. Dodge, Joseph Kartiganer \& Sherwin Kamin, Alternatives to the Current Federal Wealth Transfer Tax System, in Tax Force on Federal Wealth Transfer Taxes, Report on Reform of Federal Wealth Transfer Taxes, 58 TAX LAW. 93, 279-312 app. A (2004).

${ }^{2}$ See Stanley S. Surrey, Paul R. MCDaniel \& HarRy L. Gutman, Federal WEalth TRANSFER TAXATION 3 (rev. 2d ed. 1987). Originally enacted in 1898 as a combination estate and inheritance tax, the federal inheritance tax morphed into a tax with a rate that "graduated according to the relationship of the beneficiaries and heirs to the decedent." Id. See generally Knowlton v. Moore, 178 U.S. 41 (1900) (upholding the constitutionality of the statute, but construing it as applying rates relative to the beneficiaries and heirs, and not relative to the decedent's total estate).

${ }^{3}$ See 2008 Hearings on Alternatives, supra note 1, at 77 (statement of Professor Joseph M. Dodge) ("An inheritance tax distorts bequest choices by creating tax incentives in favor of certain classes of legatees. An inheritance tax also creates an incentive for the dispersion of wealth among legatees, but such an incentive isn't especially needed in contemporary American legal practice and culture, which has generally abandoned primogeniture."); Gerald Jantscher, Aims of Death Taxation, in DEATH, TAXES AND FAMILY PROPERTY (Edward Halbach ed., 1977), excerpted in FEDERAL TAXATION ON GRATUITOUS TRANSFERS: LAW AND PLANNING, supra note 1, at 23, 26 ("One of the most common features of the inheritance tax is the graduation of rates according to the relationship between the decedent and the recipient."). The U.S. inheritance tax during the Spanish-American War included graduated rates based on family relationships. See SURREY, MCDANIEL \& GUTMAN, supra note 2. 
preferring either closely related or unrelated recipients? With the possible exceptions for a surviving spouse who may have shared in acquiring the decedent's property, or for minor children whom the decedent was required to support in life, is not the identity of a beneficiary an inherently personal and private matter? Should the law encourage the passage of wealth to only certain beneficiaries? ${ }^{4}$

Apart from their charitable gifts, ${ }^{5}$ most wealthy decedents leave their property to other wealthy individuals, ${ }^{6}$ and the majority of beneficiaries are the decedent's close relatives. ${ }^{7}$ For the comparatively few estates with nonrelative heirs, no policy rationale supports subjecting those few unrelated individuals to either a higher or a lower tax rate. Although some scholars have supported lower rates for gratuitous transfers to more distant or unrelated beneficiaries on the basis that these transfers encourage the redistribution of wealth, the goal of "breaking up large estates" more logically refers to taxing wealthy decedents' estates so as to produce additional revenue that will either pass to the government to spend for the

${ }^{4}$ While the genetic evolution theory-proposing a primal urge to protect one's lineal descendents - may explain giving a preference to passing wealth to one's lineal descendents, the goal of equity from a tax policy standpoint does not similarly require basing a tax system on that rationale. See Theodore P. Seto, Intergenerational Decision Making: An Evolutionary Perspective, 35 Loy. L.A. L. REV. 235, 265 (2001). Professor Seto described the biological concept of kin selection:

Its relevant premise, however, is that we are motivated to care about others because we share genes with them. If this premise is carried to its logical conclusion, the strength of our motivation to care should depend on the extent to which we share genes. Thus, we should care more about our children than about our cousins, more about our cousins than about Id. strangers, and more about strangers than about nonhumans.

5 See infra Part II.D.

${ }^{6}$ See Aviva Aron-Dine, Commentary, Trade-Offs in Choosing Between an Estate Tax and an Inheritance Tax, 63 TAX L. REV. 265, 266 (2009) ("Thus, the effect is likely to be on the distribution of wealth among the very wealthy. I do not think we can reasonably expect much effect on inequality between the top and the bottom, or the top and the middle.").

${ }^{7}$ With either a transfer tax or an inheritance tax that provides large exemptions, the recipient's basic needs-in relation to the general population-are much more than adequately met. See Anne L. Alstott, Commentary, Family Values, Inheritance Law, and Inheritance Taxation, 63 TAX L. REV. 123, 128-29 (2009); Lily L. Batchelder, What Should Society Expect from Heirs? The Case for a Comprehensive Inheritance Tax, 63 TAX L. REV. 1, 16 (2009); Michael Udell, Commentary, Wealth Transfer Taxes: Benefits, Burdens, and Bases, 63 TAX L. REV. 215, 218 (2009). 
"public good" or will result in marginally ${ }^{8}$ lower taxes on the working poor and middle class. A system that distinguishes tax rates based on a fairly small number of the beneficiaries, or on a distant familial relationship (or lack thereof) of the decedent's beneficiaries, cannot realistically achieve the reduction of concentrated family wealth and its associated power. ${ }^{9}$

Another major problem with a pure inheritance tax system is that it lacks the back up of a gift tax on inter vivos transfers. ${ }^{10}$ To respond to this problem, some countries have implemented gift taxes. " Six states in the United States have enacted an inheritance tax, ${ }^{12}$ but only two states impose

${ }^{8}$ The revenue from taxes on wealth transfers is not likely to result in significant tax reductions for lower bracket taxpayers because, with large exemptions, relatively fewer taxpayers are in the taxing pool. See DODGE, GERZOG \& CRAWFORD, supra note 1, at 24; Michael J. Graetz, To Praise the Estate Tax, Not to Bury It, 93 YALE L.J. 259, 269-70 (1983).

${ }^{9}$ See Louis Kaplow, On the Taxation of Private Transfers, 63 TAX L. REV. 159, 178 (2009) ("[B] equests would to an extent be random windfalls and thus might be subjected to confiscatory taxation and redistribution, the former not having any behavioral effect."); see also STAFF OF J. COMM. ON TAXATION, 110TH CONG., DesCription AND ANALYSIS OF Alternative Wealth Transfer Tax Systems 17 (Comm. Print 2008) [hereinafter 2008 JOINT COMMITTEE PRINT], available at https://www.jct.gov/publications.html?func=fileinfo \&id=1318 ("Studies have found that more than two-thirds of testate decedents with multichild families divide their estates exactly equally or very close to equally."). Yet, equal division of very large estates means that each child receives a very large windfall, and that family wealth is still family wealth.

${ }^{10}$ See United States v. Irvine, 511 U.S. 224, 234 (1994); Smith v. Shaughnessy, 318 U.S. 176, 179 (1943) (supplementing the estate tax with the gift tax); Estate of Sanford v. Comm'r, 308 U.S. 39, 44 (1939); DODGE, GERZOG \& CRAWFORD, supra note 1, at 35.

11 See 2008 Jont CommitTeE Print, 110Th CONG. at 7-9 (Finland, Germany, Ireland, and Spain).

${ }^{12}$ See IOWA CODE $\S 450.3$ (2014); Ky. Rev. STAT. ANN. $§ 140.010$ (LexisNexis 2010); MD. Code ANN., TAX-GeN. $§ 7-2$ (LexisNexis 2010); NEB. REV. STAT. $§ 77-2001$ (2013); N.J. Rev. Stat. § 54:5-1 (2014); 72 PA. Cons. Stat. ANN. § 9116 (West 2000 \& Supp. 2013). Since 1989, Tennessee's inheritance tax (although the state nominally retained the tax) has not made distinctions on rates or exemptions because of the beneficiaries relation to the decedent, and its progressive rates are dependent on the estate's value, ranging from 5.5\%-9.5\%. See TENN. CODE ANN. \$§ 67-8-314(a), -8-316(a)(2) (2013). Because the tax more closely resembles an estate tax, Tennessee is not included as a state with an inheritance tax. Tennessee repealed its "inheritance" tax for decedents dying after 2016. See id. § 67-8314(b). Indiana recently repealed its inheritance tax for decedents dying on or after January 1, 2013. See IND. CODE ANN. § 6-4.1-11-2 (LexisNexis 2007) (repealed 2013). Likewise, in 2012 , Oregon eliminated its inheritance tax and substituted a state estate tax that is applicable to decedents dying on or after January 1, 2012. See Estate and Trust Taxes, OR. DEP'T OF REVENUE, www.oregon.gov/dor/bus/pages/inheritance.aspx (last visited Mar. 31, 2014). 
a gift tax and those states - Connecticut and Minnesota ${ }^{13}$ - do not have an inheritance tax (although they do have a state estate tax). ${ }^{14}$ Some states, however, do include some lifetime transfers in their inheritance tax regimes, but outright gifts that are not in contemplation of death or within a few years of death are not subject to any state inheritance tax. ${ }^{15}$ Thus the very wealthiest of individuals who have many times the funds necessary to maintain a high standard of living and cover their unexpected expenses are most able to avoid an inheritance tax through early lifetime gifts. ${ }^{16}$

Compounding this problem is that inheritance taxes do not generally apply to gifts over which the decedent retained control until, or shortly before, his death despite that those transfers may well be described as testamentary. Hence, wealthy individuals are able to avoid the tax as they are more likely to make lifetime transfers when they can retain control over the transferred property during their lifetimes. More so, the exemption from inheritance tax systems of lifetime gifts with retained powers contrasts sharply to the inclusion of such transfers under the current estate tax provisions-Internal

${ }^{13}$ See Judith Lohman, CONN. GEN. AsSEMBLy, OfFICE OF LEGIS. RESEARCH, LEGISLATIVE HISTORY OF THE CONNECTICUT ESTATE TAX SINCE 2001 (2010), available at cga.ct.gov/2010/ $\mathrm{rpt} / 2010-\mathrm{R}-0226 \mathrm{htm}$ ("In 2005, Connecticut revamped its taxes on inheritances and gifts. It repealed the succession tax, which it was already phasing out, and it combined the state estate and gift taxes into one transfer tax with the same rates."). The Connecticut gift and estate taxes replicate their federal transfer tax counterparts but with lower exemption levels and rates (total of $\$ 2$ million gift or estate exemption and maximum rate of $12 \%$ ). See id. at tbl.5. Connecticut's succession tax was a typical inheritance tax: "Whether the tax applied and at what tax rate depended not only on the value of the inheritance but also on the relationship of the heirs to the decedent." Id. The tax system provided four classes of heirs with the lowest rates applicable to a decedent's closest relatives and the highest rates for the decedent's distant relatives and unrelated persons. See id. Recently, in its 2013 Omnibus Tax Act, Minnesota enacted a state gift tax effective for gifts made after June 30, 2013. See H.R. 677, 2013 Leg., 88th Sess. (Minn. 2013) (subjecting the excess of $\$ 1$ million in aggregate lifetime and testamentary transfers to its state transfer taxes). The purpose of enacting the state gift tax was "to complement or back up the Minnesota estate tax." ANN LENCZEWSKl, HOUSE RESEARCH BILl SUMMARY, H.F. 2013677, 88th Sess., at 28 (2013) (Conf. Rep.), available at http://www.house.leg.state.mn.us/ $\mathrm{hrd} / \mathrm{bs} / 88 / \mathrm{HF} 0677 . \mathrm{pdf}$.

${ }^{14}$ Tennessee, which has a nominal inheritance tax, recently repealed its state gift tax for gifts made on or after January 1, 2012. See TENN. CODE ANN. \$ 67-8-101(a)(2). Kentucky has not had a state estate tax since January 1, 2005. See Ky. DeP'T of REVENUE, A GuIDE to KENTUCKY INHERITANCE AND ESTATE TAXES: GENERAL INFORMATION 2 (2011), available at http://revenue.ky.gov/NR/rdonlyres/6D844DC9-B300-4EE7-963E-DB141FC0AED6/0/ guide 2011.pdf.

${ }^{15}$ See discussion infra Part II.A.

${ }^{16}$ See discussion infra Part II.A. 
Revenue Code (Code) sections 2036 and 2038. Those provisions require the application of estate taxation to transfers with retained control, and in so doing, they function as important anti-abuse mechanisms.

Because many state inheritance tax systems depend heavily on the current transfer tax system for pivotal definitions, any new system would likely need to borrow or replicate much of the law and language of the current transfer tax system. ${ }^{17}$ Specifically, various state inheritance tax statutes use federal law definitions to determine marital and charitable deductions qualifications. ${ }^{18}$ Likewise, at least one state statute cites to the federal gift tax annual exclusion and spousal-gift-splitting statutes. ${ }^{19}$

The thorniest questions and abuses in the transfer tax area involve valuation distortion. ${ }^{20}$ For the most part, those difficulties would not disappear with an inheritance tax and would resurface in that alternative tax system. $^{21}$ Additionally, in an inheritance tax regime, fractional interest discounts would proliferate. ${ }^{22}$ With any of the recent proposals ${ }^{23}$ that are

${ }^{17}$ See, e.g., Batchelder, supra note 7, at 65 ("Despite this fundamental change in the form of wealth transfer taxation, the proposal would continue to rely on much of the extensive body of laws, regulations, and guidance that have been developed under the U.S. estate tax system. For example, the existing rules governing when a transfer has occurred, how it is valued, and what transfers are taxable would remain unchanged. The proposal would not tax a large portion of wealth transfers, as under current law."). Moreover, Professor Batchelder states: "To the extent that the current tax treatment of accrued gains, generation-skipping transfers, income in respect of a decedent, illiquid assets, charitable contributions, and gifts made during life for education and medical expenses are considered desirable or politically necessary, these exemptions could be maintained." Id.

${ }^{18}$ See, e.g., IOWA CODE $\S 450.3(7)$ (a) (2014) (referencing the federal qualified terminable interest property (QTIP) under Code section 2056(b)(7)(B)).

${ }^{19}$ See id. $\$ 450.3$ (2) (citing both the exclusions "under section 2503, subsections (b) and (e), of the Internal Revenue Code" and to gift splitting as allowed "in section 2513 of the Internal Revenue Code").

${ }^{20}$ See, e.g., Karen C. Burke \& Grayson M.P. McCouch, Commentary, Family Limited Partnerships: Discounts, Options, and Disappearing Value, 6 FLA. TAX REV. 649 (2004); Mary Louise Fellows \& William H. Painter, Valuing Close Corporations for Federal Wealth Transfer Taxes: A Statutory Solution to the Disappearing Wealth Syndrome, 30 STAN. L. REV. 895 (1978); Wendy C. Gerzog, Valuation Discounting Techniques: Terms Gone Awry, 61 TAX LAw. 775 (2008); Brant J. Hellwig, On Discounted Partnership Interests and Adequate Consideration, 28 VA. TAX REV. 531 (2009); James R. Repetti, Minority Discounts: The Alchemy in Estate and Gift Taxation, 50 TAX L. REV. 415 (1995); Walter D. Schwidetzky, Family Limited Partnerships: The Beat Goes On, 60 TAX LAw. 277 (2007).

${ }^{21}$ See infra Part V.

22 See 2008 Joint Committee Print, 110Th Cong. 22 (Comm. Print), available at https://www.jct.gov/publications.html?func=fileinfo $\&$ id $=1318$. 
offered as substitutes for the present transfer tax system, property values would still need to reflect fair market value accurately; and in any system (including the current transfer tax system) valuation reform would need to occur. $^{24}$

In 2009, Professor Lily Batchelder made an innovative proposal to create a comprehensive inheritance tax (CIT) to replace the current transfer tax system and to tax large gifts and bequests as income. ${ }^{25}$ She incorporates from existing inheritance tax systems the focus on the recipient of a gift or bequest because, as her data shows, ${ }^{26}$ the burden of the estate tax falls mainly on the beneficiary. ${ }^{27}$ According to her, approximately one-fifth of the recipients bear a disproportionate weight under the current transfer tax. ${ }^{28}$

${ }^{23}$ See id. at 2-4. Scholars have proposed alternatives such as a deemed-realization approach, an inheritance tax, an accessions tax, an income-inclusion tax, and various hybrid approaches. See DodGe, Gerzog \& CraWford, supra note 1, at 22-23; Joseph M. Dodge, A Deemed Realization Approach Is Superior to Carryover Basis (and Avoids Most of the Problems of the Estate and Gift Tax), 54 TAX L. REV. 421 (2001); Joseph M. Dodge, Beyond Estate and Gift Tax Reform: Including Gifts and Bequests in Income, 91 HARV.L. REV. 1177 (1978); Joseph M. Dodge, Comparing a Reformed Estate Tax with an Accessions Tax and an Income-Inclusion System, and Abandoning the Generation-Skipping Tax, 56 SMU L. REV. 551 (2003); Joseph M. Dodge, Taxing Gratuitous Transfers Under a Consumption Tax, 51 TAX L. REV. 529 (1996).

${ }^{24}$ See 2008 JoInt COMMITTE PRINT, 110 Th CONG. at 22 (citing STAFF OF J. COMM. ON TAXATION, OPTIONS TO IMPROVE TAX COMPLIANCE AND REFORM TAX EXPENDITURES, JCS02-05, at 396-404 (2005)) (proposing rules that would limit the use of minority and marketability discounts under the present U.S. estate and gift tax system).

${ }^{25}$ See Batchelder, supra note 7. The CIT is a proposed replacement for the current transfer tax system that is integrated into the current income tax system and has features of a cumulative accessions tax. See id. at 62-64. Each recipient of gifts and inheritances exceeding $\$ 1.9$ million (plus $\$ 13,000$ annual gifts and $\$ 65,000$ in annual bequests) must include those amounts in income at the beneficiary's tax bracket plus an additional $5 \%$ surtax. See id. Bequests, like gifts currently, would receive a carryover basis. See id. Professor Batchelder outlined a detailed explanation of the CIT tax treatment of a multitude of assets and transfers. See id. This Article's discussion of the CIT is highly abbreviated, but it includes a discussion of the CIT as the sole proposed, rather than actual, inheritance tax because of its significant addition to the scholarship on this topic. See 2008 JOINT COMMITTEe PrinT, 110TH CONG. at 14.

${ }^{26}$ Batchelder, supra note 7, at 4 ("In addition, none has maintained that wealth transfer taxes predominantly burden heirs, or provided estimates of the distributional effects of wealth transfer taxes at an heir level.").

${ }^{27}$ However, the actual beneficiary with the burden of taxation depends upon how the decedent allocated that burden in his or her will or trust documents. Without a clear directive from the decedent, federal statutory presumptions-like those in sections 2205, 2206, 2207, $2207 \mathrm{~A}$, and 2207B - apply, or state apportionment nules control. That is, in fact, only one 
Professor Batchelder correctly points to the inequity between the wealthy and less wealthy beneficiaries; ${ }^{29}$ however, her numbers do not explain to what extent this onus is the result of the decedent's design, or is the result of the applicable apportionment statute, or is the consequence of a lack of progressivity in our current flat transfer tax rate or an estate planning technique. Primarily, the decedent controls the assignment of any tax and debt burden among his beneficiaries. Those costs may be assigned equitably or unevenly distributed among heirs. For example, a decedent with two children can shift the tax burden to his wealthier child. Even understanding that an equal division may unfairly burden his poorer child, the decedent may still opt not to shift the tax burden or not to divide his property unevenly to offset this effect. The decedent may, for example, simply want to reward his more successful child who is more like himself. Thus the decedent may think that he is being fair: Each child receives an equal amount. If that equal division results in one child shouldering more of the expense, that may be the parent's choice.

If a decedent is silent or unclear on the issue of tax and debt burden apportionment in his will or trust instrument, federal tax reimbursement statutes or state apportionment laws may control which beneficiaries must bear the expense, and that result may be equitable (that is, to the extent that the transferred property incurs a tax) or inequitable (like in burden-on-the-

heir (under a burden-of-the-residue-testamentary provision or state fallback rule) may have that burden despite other heirs being recipients of taxable estate assets.

${ }^{28}$ See 2008 Hearings on Alternatives, supra note 1, at 32 app. (statement of Professor Lily Batchelder) ("As Table 1 shows, in 2009 only about 5 in 1,000 people who receive an inheritance will bear any estate tax burden. In part, this is because more than 30 percent of heirs inheriting between $\$ 2.5$ and $\$ 5$ million are not burdened by the estate tax at all. Generally these heirs have inherited all or part of an estate just below the exemption threshold. Meanwhile about 4 percent of those inheriting between $\$ 500,000$ and $\$ 1$ million are burdened by the estate tax, often at quite high rates. Typically these heirs have inherited a much smaller amount from an even larger estate."); Batchelder, supra note 7, at 3 ("Surachai Khitatrakun and I estimate that about $22 \%$ of heirs burdened by the U.S. estate tax have inherited less than $\$ 500,000$, while $21 \%$ of heirs who inherit more than $\$ 2,500,000$ bear no estate tax burden.").

29 See Batchelder, supra note 7, at 69 ("In aggregate, the distributional effects of the proposal are fairly similar to the estate tax system. As illustrated by Figures 15 and 16, the proposal is somewhat more progressive by economic income and inheritance size, but the differences are not dramatic. Heirs with economic income of less than $\$ 500,000$ or inheritances below $\$ 2.5$ million bear higher average tax rates under the estate tax. Meanwhile, those with economic income or inheritances exceeding these amounts bear higher burdens under the [CIT] proposal."); see also infra Part III. 
residue jurisdictions). ${ }^{30}$ Thus, other federal tax statutes or state law may at least, to some extent, control the inequity Professor Batchelder finds. Those laws are fallback provisions that come into effect when a decedent does not specifically state which beneficiaries will bear the tax responsibility. Finally, when there are insufficient burdened assets to cover the decedent's liabilities, the government will pursue its debt either from the executor ${ }^{31}$ or from any and all beneficiaries to the extent of the value of the property those beneficiaries receive from the estate. ${ }^{32}$

Notably, by means of an irrevocable life insurance trust (ILIT)-a common estate planning technique - the decedent can effectively finance the costs of estate taxes at a significant discount both to the decedent and to his or her family. ${ }^{33}$ That is, the proceeds of life insurance on the decedent's life are not included in the decedent's estate when the policy is owned solely by the ILIT (and not transferred by the decedent to the ILIT within 3 years of his death) even if the decedent paid the insurance premiums. ${ }^{34}$ Yet, the decedent can use the untaxed proceeds to provide additional funds and liquidity for his estate. So, to some extent, often neither the decedent nor the beneficiaries has the burden of paying a significant portion of the estate tax bill. ${ }^{35}$

An ILIT is often incorporated into an estate plan in second marriages when an age disparity exists between the spouses and the older spouse has adult children from an earlier marriage who are similar in age to the younger spouse. When the older spouse dies, he may leave funds to those children through an ILIT. ${ }^{36}$ However, because the proceeds of an ILIT are

${ }^{30}$ See Wendy C. Gerzog, Equitable Apportionment: Recent Cases and Continuing Trends, 41 REAL Prop. ProB. \& TR. J. 671, 672-79 (2007).

${ }^{31}$ The executor must pay the taxes before distributing the property to beneficiaries or he may be responsible for that expense. See I.R.C. $\S 6901$ (a); 31 U.S.C. $\S 3713$ (b) (2006). Pursuant to sections 2204(a) and 6905(a), executors can limit their liability by filing the appropriate tax returns and then filing an application (Form 5495).

${ }^{32}$ See I.R.C. $\$ 6324(a)(2)$. Under this statute, an individual beneficiary may be liable, even for estate taxes relating to another beneficiary's property, up to the amount of property that the individual has received from the estate. See id.

33 See infra note 85 and accompanying text.

34 See id.

${ }^{35}$ See id. Thus, Professor Batchelder's statistics do not reflect how much of the $22 \%$ are so burdened because of the current transfer tax system and not because of other factors such as the decedent's design or the effect of other laws; therefore, the inequity she finds may be less than her figures suggest.

${ }^{36}$ See, e.g., Richard E. Bames, Till Death Do Us Part (Again), ProB. \& Prop., March/April 2007, at 34, 36 ("When appropriate, a large outright distribution, an irrevocable 
not subject to estate tax, those bequests would not be a part of Professor Batchelder's data.

Moreover, Professor Batchelder's information may simply argue for reinstituting a more progressive rate structure into the current flat transfer tax rates. ${ }^{37}$ The heirs most burdened are likely to be the ones whose deceased parent or relative is at the margins of taxability in the current transfer tax system and not those heirs of the mega-rich who are each likely to be welloff. Currently, the flat transfer tax rate is $40 \%{ }^{38}$ in contrast to the progressive rates in effect prior to the Tax Act of 2001, which ranged from $37 \%$ to $55 \%$. ${ }^{39}$ Especially with the current larger exemptions ( $\$ 5.34$ million combined estate and gift tax exemption in 2014 compared to the $\$ 1$ million gift tax and the $\$ 3.5$ million aggregate transfer tax exemption in 2009 when Professor Batchelder published her CIT proposal), ${ }^{40}$ the skewed burden Professor Batchelder addresses more likely affects a smaller minority of

life insurance trust naming the children as beneficiaries, or a QTIP trust capped at a fraction of the estate may provide funds for the children immediately while still providing for the surviving spouse and lessening the animosity between the children and the younger spouse.").

${ }^{37}$ See 2008 Hearings on Alternatives, supra note 1, at 3 (statement of Professor Lily Batchelder) ("Some people receiving relatively modest bequests may bear a substantial tax burden if they are inheriting from an extremely large estate, and some people receiving really extraordinarily large inheritances may bear no estate tax burden if they are receiving from one or more estates that are just below the lifetime exemption."). Professor Batchelder illustrates the tax burden disparity by comparing those estates below the exemption amount (and therefore not taxed under the current transfer tax system) with taxable estates in which heirs receive relatively small inheritances. Her point is well-argued and supported, though her data reflects that the vast majority of recipients do not have this problem. Her data, moreover, does not consider the decedent's intentions nor federal reimbursement statutes and state apportionment laws' roles in placing the burden on the beneficiary. Likewise, the $22 \%$ figure might well be further reduced by the re-imposition of more progressive rates for those estates just over the exemption amount. See discussion infra Part III. With the increased exemption of $\$ 5.34$ million, moreover, that figure for unfairly burdened heirs might already be substantially decreased. See infra note 40 and accompanying text. Finally, more data needs to be collected about how many nonstudent adult heirs are in the lower income tax brackets.

${ }^{38}$ See American Taxpayer Relief Act of 2012, Pub. L. 112-240, 126 Stat. 2313, $\S 101(c)(1)$ (Jan. 2, 2013) (codified as amended at I.R.C. $\$ 2001(c)$ ).

39 See Staff of J. COMm. On TAXation, 107Th CONG., GenERal EXPLANation OF TAX Legislation 57-58 (Comm. Print 2003) [hereinafter 2001 ACT EXPLANATION]; see also Ronald D. Aucutt, Estate Tax Changes Past, Present and Future 6 (2014), available at http://www.mcguirewoods.com/news-resources/publications/estate-tax-changes.pdf.

${ }^{40}$ See AUCUTT, supra note 39; What's New-Estate and Gift Tax, IRS, http://www.irs. gov/Businesses/Small-Businesses-\&-Self-Employed/Whats-New-Estate-and-Gift-Tax (last updated Apr. 9, 2014); see also DODGE, GERZOG \& CRAWFORD, supra note 1, at 55-58. 
heirs today. Also, those facts may point to a simpler solution than instituting a completely new tax like an inheritance tax or the CIT.

Some scholars, including Professor Batchelder, ${ }^{41}$ have argued on redistribution grounds that tax preferences should be given to decedents who pass property to less wealthy distant relatives or unrelated individuals. ${ }^{42}$ Indeed, the feature of the CIT that emphasizes the relationship between the transferor and the transferee is one that underlines its identity as a type of inheritance tax rather than as a pure income-inclusion system. However, a tax preference for remotely related or unrelated recipients of the decedent's wealth does not and cannot equate with the goal of "breaking up large estates," a purported objective of the transfer tax system. ${ }^{43}$ Decedents

${ }^{41}$ See Batchelder, supra note 7, at 69 ("In reality, the proposal would probably be even more progressive than the current system because these estimates assume no behavioral response. To the extent that donors respond to the incentives created by the proposal to give more widely and to those with less pre-inheritance income, pretax inheritances should become more progressive . . . [T] here is little, if any, evidence on which to base an estimate of this response.").

${ }^{42}$ See Anne L. Alstott, Equal Opportunity and Inheritance Taxation, 121 HARV. L. REV. 469, 511 (2007) ("With these principles in place, we can now see that the equal opportunity perspective suggests a striking departure from the European inheritance tax model and from prior proposals for accessions taxation. Instead of taxing gifts and bequests from closer relatives at lower rates, the inheritance tax should tax bequests from relatives in full and should exempt those from nonrelatives."). However, Professor Alstott acknowledged not only are those transfers unusual but they might also encourage abuse: "Gifts and bequests from unrelated individuals are rare today, but the danger is that they might become the newest shelter for the rich." Id. at 512.

${ }^{43}$ See, e.g., Jantscher, supra note 3, at 23-27. Besides countering the concentration of economic and political power in the wealthiest individuals and families, stated rationales for taxing wealth transfers include increasing revenue, equalizing opportunity, encouraging additional income tax progressivity, and a backstop to the income tax regime. See, e.g., Wojciech Kopczuk, Economics of Estate Taxation: Review of Theory and Evidence, 63 TAX L. REV. 139, 152 (2009) ("Suppose that high wealth concentration has a negative effect on the welfare of the society. If this is the case, then the targeting principle would call for a tax hitting wealth concentration. The current estate tax is precisely that kind of a tax: It affects only those with high wealth. Why might one think that wealth concentration is undesirable? For one thing, some of the world's worst-governed countries exhibit a high concentration of wealth. While correlation does not imply causality, it is at least consistent with the notion that a concentration of wealth, that is, the situation in which some individuals are big relative to the state, has an adverse effect on the political process or constitutes a danger to democracy. This was one of the main arguments used when the estate tax was introduced in the United States."); Thomas Nagel, Liberal Democracy and Hereditary Inequality, 63 TAX L. REV. 113, 117-18 (2009) ("If contemporary fortunes are not whittled down by inheritance taxes and the donations to charity that such taxes encourage, we will find ourselves with a greatly enlarged long-term dynastic upper class of inordinate wealth .... A dynastic system 
generally give their assets to relatively few loved ones. ${ }^{44}$ Indeed, despite claims by those who expect that an inheritance tax would change a decedent's behavior increasing the number of beneficiaries to whom a decedent would pass her property, some evidence shows that this logical result would not occur. ${ }^{45}$

Finally and most haltingly, focusing on beneficiaries rather than on the decedent multiplies the number of taxpayers involved in reporting transactions that are inherently difficult to police. Our history with unreported tip income when third parties are usually involved, should provide a warning of the difficulty of enforcement in the area of family gifts. ${ }^{46}$ Compliance rates would decrease significantly under an incomeinclusion or CIT system, and administrative costs would increase.

The purpose of this Article is to identify and critique common characteristics of the inheritance tax systems that exist in the United States and internationally, particularly in Europe, using the current-albeit imperfect-federal transfer tax system as a benchmark. In addition, the Article examines the novel CIT proposal offered by Professor Batchelder that takes some elements of existing inheritance taxes as well as some

that is allowed simply to float free of societal control is not merely a form of economic inequality, but a form of exemption of members of the privileged class from the minimal conditions of social solidarity."); see also 2008 JOINT COMMITTEE PRINT, 110TH CONG. 1-2 (Comm. Print), available at https://www.jct.gov/publications.html?func=fileinfo\&id=1318. For arguments in favor of a high exemption to retain the positive attributes of family wealth, see Nagel, supra at 120.

${ }^{44}$ See Kopczuk, supra note 43, at 141 ("Interpersonal externalities should not be ignored in a debate about transfers, but their relevance, in my view, is potentially important only when we are considering transfers throughout the distribution, rather than transfers at the top of the distribution, as is the case in the context of the current transfer taxation in the United States."). Despite having hundreds or even thousands of Facebook friends, most decedents have very few people they want to give or leave their property to, and most of those beneficiaries are in the same socio-economic stratum as the decedents.

${ }^{45}$ Data indicates that the wealthy do not take advantage of certain transfer tax benefits because of stronger motivational reasons such as fear of insufficient assets later in life or, more significantly, a desire to retain control over those who will likely be their ultimate beneficiaries. See infra text and accompanying notes 131-136. Also, parents most likely would still make most of their gifts and bequests to their children. See Kaplow, supra note 9, at 175 ("[M]ost gifts are to relatives, the largest being from parents to children."). Perhaps the genetic evolution theory may also support the proposition that such an upside down principle would never be enacted in the first place. See Seto, supra note 4.

${ }^{46}$ See John Robertson, Tina Quinn \& Rebecca C. Carr, Unreported Tip Income: A Taxing Issue, CPA JouRNAL (Dec. 2006), available at http://www.nysscpa.org/cpajournal/ 2006/1206/essentials/p30.htm. 
features of the current transfer tax system and embeds them into the income tax system.

\section{EXISTING INHERITANCE TAX SySTEMS}

\section{A. Inter Vivos Transfers}

Just as the U.S. gift tax was enacted to supplement and prevent erosion of the estate tax ${ }^{47}$ many international inheritance taxes include some kind of taxation on gifts. ${ }^{48}$ For example, Germany, Ireland, Spain, and Finland subject gifts over an exemption amount either to a gift tax or to an inheritance tax. ${ }^{49}$ Currently only six states in the United States impose an inheritance tax, ${ }^{50}$ and none of those states also impose a state gift tax, although five states with an inheritance tax also have a state estate $\operatorname{tax}^{51}$ and two states with an inheritance tax also have a state generation-skipping transfer (GST) tax. ${ }^{52}$ Some states with inheritance taxes include gifts

${ }^{47}$ See SURREY, MCDANIEL \& GUTMAN, supra note 2, at 4 ("As soon as the estate tax became law, wealthy persons sought to avoid its provisions by transferring their property before death.").

${ }^{48}$ See 2008 Hearings on Alternatives, supra note 1, at 77 (statement of Professor Joseph M. Dodge) ("Finally, it is hard to integrate a gift tax with an inheritance tax."). Most often, an inheritance tax is an annual tax on gratuitous receipts. See 2008 JOINT COMMITTEE PRINT, 110TH CONG. at 7, n.21.

${ }^{49}$ See id. at 8-9.

${ }^{50}$ See supra note 12 and accompanying text.

${ }^{51}$ See IOWA Code $\$ \S 451.2,451.4$ (2014); KY. REV. STAT. ANN. $\$ 140.130$ (LexisNexis 2010); MD. CODE ANN., TAX-GEN. § 7-302 (LexisNexis 2010); N.J. REV. STAT. § 54:38-1 (2014); 72 PA. CONS. STAT. ANN. $\$ 9117$ (West 2000 \& Supp. 2013); see also IND. CodE ANN. $\S \S 6-4.1-11-1,-11-2$ (LexisNexis 2007) (repealed for decedents dying on or after January 1, 2013).

52 See IOWA CODE $\S 450$ A. 2; MD. CODE ANN., TAX-GEN. § 7-402(6) (imposing a tax on GSTs that are not a "direct skip" under section 2612 of the Code when on the date of the original transfer the original transferor was either a Maryland resident or a nonMaryland resident and the property has a situs in Maryland); see also IND. CODE ANN. § 6-4.1-11.5-7 (repealed for decedents dying on or after January 1, 2013). According to Professor Hines, the CIT does not include transfers currently subject to the federal GST. See James R. Hines, Jr., Taxing Inheritances, Taxing Estates, 63 TAX L. REV. 189, 202 (2009). Indeed, whether Professor Batchelder would keep a GST tax in the CIT is unclear. She states: "To the extent that the current tax treatment of ... generation-skipping transfers ... are considered desirable or politically necessary, these exemptions could be maintained." Batchelder, supra note 7, at 65. However, Professor Batchelder proposes that the CIT have its own type of GST tax with an emphasis on the ultimate beneficiary. See Batchelder, supra note 7, at 66-67 ("Finally, the proposal would tax transfers to grandchildren (and more distant lineal descendents) as if the amount inherited had first passed first to their parents (and any 
transferred within a specified number of years before the decedent's death in their inheritance tax base. ${ }^{53}$ To the extent that an inheritance tax does not include all lifetime gifts, however, that inheritance system allows the very wealthy to avoid the tax because the wealthiest of individuals can most afford to make early-in-life large transfers to their loved ones. ${ }^{54}$

Some transfers that are generally not subject to an inheritance tax are those inter vivos gifts that include assets over which the donor has retained

additional skipped generations), and only then to the actual heirs. In practice, this would be accomplished by applying an implicit tax to the skipped heir at the top tax rate, unless the recipient presented evidence of what the skipped heir would have owed if the funds had actually passed to them initially. This treatment should apply regardless of whether the transfer is made directly or through a trust.").

${ }^{53}$ Iowa does not have a gift tax, but the state's inheritance tax includes most gifts made within 3 years of death. See IOWA CODE $§ 450.3(2)$. Likewise, Kentucky's inheritance tax includes gifts made within 3 years of a decedent's death unless shown that the decedent did not make the gift in contemplation of his or her death. See KY. REV. STAT. ANN. § 140.020(2). Whether a transfer made more than 3 years prior to the decedent's death was made in contemplation of death is a factual question determined by "the proper tribunal." Id.; see also KY. DEP'T OF REVENUE, supra note 14, at 9. Maryland's inheritance tax includes gifts intended to take effect in possession or enjoyment at or after the decedent's death, gifts in contemplation of death, and transfers within 2 years of death even if not in contemplation of death. See MD. CODE ANN., TAX-GEN. $\S 7-201(d)(1)$. Nebraska subjects transfers within 3 years of death to inheritance taxes when a federal gift tax return must be filed. See NEB. REV. STAT. § 77-2002(2) (2013). Pennsylvania's inheritance tax taxes transfers within 1 year of death as long as that transfer in the aggregate exceeds $\$ 3,000$ in any calendar year. See 72 PA. Cons. STAT. ANN. $\S 9107(\mathrm{c})(3)$ (West 2000 \& Supp. 2013). When the federal estate and gift tax systems became unified under one rate system and credit in 1976 (although the taxes were not unified between 2002 and 2010), subjecting most transfers made within 3 years of death to federal estate tax became unnecessary. See DODGE, GERZOG \& CRAWFORD, supra note 1, at 33-34 ("The transferin-contemplation-of-death provision has been greatly watered down. What's left of it is located in $\S 2035$. The 'testamentary effect' idea has undergone gradual evolution over the years, and has been dispersed over Code $\S \S 2036-2039$. Thus, the following nonprobate items attributable to inter vivos transfers are currently included in the gross estate: (1) the proceeds of insurance on the decedent's life where the insured owned the policy and made a gift of it within three years of death ( $\$ 2035(a)$ ); (2) gift tax paid (or owed) on gifts made within three years of death $(\S 2035(b)) ; \ldots .$. .). However, unlike federal law that subjects transfers of certain retained powers or interests made within 3 years of death under section 2035(a)(2), New Jersey's inheritance tax exempts such transfers from its inheritance tax. See N.J.REV. STAT. § 54:34-1.1 (2014). Gifts of retained rights or powers made more than 3 years prior to death are deemed not made in contemplation of death. See id.

${ }^{54}$ See Margaret Collins, Rich Passing Up \$10 Million Opportunity to Gift Tax-Free, BLOOMBERG (July 13, 2012, 12:01 AM), http://www.bloomberg.com/news/2012-07-13/richpassing-up-10-million-opportunity-to-gift-tax-free.html ("For families with more than $\$ 100$ million, deciding to transfer as much as $\$ 10$ million now may be an easier decision because it's a much smaller percentage of their net worth ...."). 
control until his or her death. ${ }^{55}$ The federal estate tax ensures that those types of lifetime transfers are included in the decedent's taxable estate. ${ }^{56}$ If a decedent makes a gift but retains either a life interest in that property ${ }^{57}$ or a

55 Iowa also includes property either subject to a general power of appointment held by the decedent at his or her death, or properly exercised or released within 3 years that, if decedent had owned the property outright, would have been includible in his or her estate under this section. See IOWA CODE $\S 450.3(2)$. The tax treats a transfer creating a general power of appointment as a fee property interest transfer and treats other types of powers of appointment other than those when the donee makes an election "as the transfer of a life estate or term of years in the property subject thereto to the donee of the power and as the transfer of the remainder interests to those who would take if the power is not exercised." Id. $\S 450.3(4)$. Also, a transfer subject to the decedent's secret request shall be treated as a transfer subject to the highest inheritance tax rate. See id. Kentucky's inheritance tax provides for the inclusion of gifts when the decedent intends for that gift to take effect at or after decedent's death:

[I]ncluding a transfer under which the transferor has retained for his life or any period not ending before his death (a) the possession or enjoyment of, or the income from the property; or (b) the actual or contingent power to designate the persons who shall possess the property or the income therefrom, except in the case of a bona fide sale for an adequate and full consideration ....

KY. REV. STAT. ANN. $§ 140.020$ (1). Kentucky's inheritance tax also applies when the settlor has a testamentary power to revoke a lifetime gift. See id. In its inheritance tax system, Maryland includes gifts in which "the decedent retain[s] any dominion over the transferred property" during his life, including a retained interest, any type of power of revocation, or a power of appointment. MD. CODE ANN., TAX-GEN. §§ 7-201(d)(iii)(4), 7-202. Pennsylvania's inheritance tax includes gifts in which the decedent retains control over assets until death. See 72 PA. CONS. STAT. ANN. § 9107(c)(4)-(7). Pennsylvania's inheritance tax provisions include parallels to the current estate tax sections 2036(a)(1), 2036(a)(2), 2037 , and 2038, utilizing almost the same language and requirements of those federal estate tax statutes. See id. In addition, Pennsylvania's inheritance tax includes transfers in which the transferee promises either to pay or to take care of the transferor for the duration of the transferor's life as well as section 2038-type transfers in which the power is relinquished within 1 year of the transferor's death. See id. Thus, while not subjecting early outright gifts to its inheritance tax, Pennsylvania broadly includes the decedent's lifetime gifts in its inheritance tax with retained interests or control; by copying the federal estate tax abuse prevention statutes, the Pennsylvania inheritance tax uniquely captures more gratuitous transfers than most inheritance taxes. See id.

${ }^{56}$ See I.R.C. $\$ \S 2036-2038$. Section 2035 includes the date-of-death value of such property transfers when the decedent transfers her retained interest or power within 3 years of her death. See I.R.C. $\$ 2035$.

${ }^{57}$ See I.R.C. $\$ 2036(a)(1)$. Section 2036 applies to transfers when a decedent retains either the income from income producing property or the present enjoyment of nonincome producing property for his or her life, for any period not ascertainable without reference to his or her death, or for any period that does not end before his or her death. See id. 
power to control the lifetime possession or enjoyment of that property, ${ }^{58}$ the full date-of-death value of that property will be included in his or her estate by means of the estate tax. ${ }^{59}$

Early case law described these types of transfers with lifetime-retained control or a lifetime-retained property interest as "will substitutes.", 60 Congress quickly reacted to three Supreme Court cases ${ }^{61}$ that allowed decedents to avoid estate taxes for gifts of transferred property that the decedents had retained a lifetime right to enjoy. ${ }^{62}$ Congress enacted that statute, substantially the same as the current one, to prevent tax avoidance. ${ }^{63}$

${ }^{58}$ See I.R.C. $\S 2036(a)(2)$. Section 2038 applies also to such powers although this section's application requires inclusion of only the value of the income interest remaining at a decedent's death as calculated under the actuarial tables. See I.R.C. $\S 2038$ (a)(2). Thus, these two sections overlap in some respect.

${ }^{59}$ See I.R.C. $\$ 2036$ (a). However, when the property itself, and not the income interest, is subject to a retained power, only the value of the remainder interest at a decedent's dateof-death is included in his or her estate. See also I.R.C. $\$ 2038$; Treas. Reg. $\S 20.2038-1$ (a).

${ }^{60}$ See, e.g., Helvering v. Hallock, 309 U.S. 106, 114 (1940).

${ }^{61}$ See Burnet v. N. Trust Co., 283 U.S. 782 (1931) (per curiam); Morsman v. Burnet, 283 U.S. 783 (1931) (per curiam); McCormick v. Burnet, 283 U.S. 784 (1931) (per curiam).

${ }^{62}$ See United States v. Byrum, 408 U.S. 125, 160, 165 (1972) (White, J., dissenting); Comm'r v. Estate of Church, 335 U.S. 632, 640 (1949) ("Both houses of Congress unanimously passed and the President signed the requested resolution that same day.").

${ }^{63}$ Acting Secretary of the Treasury Ogden Mills stated that without congressional action to reverse the three Supreme Court opinions, the resulting loss to the Treasury would be "in excess of one-third of the revenue derived from the federal estate tax, with anticipated refunds of in excess of $\$ 25,000,000$." Estate of Church, 335 U.S. at $639-40$ (citations omitted) (internal quotation marks omitted); see also Byrum, 408 U.S. at 159-60 (White, J., dissenting). The dialogue between the following Congressmen underscores this intent:

Mr. HAWLEY. Mr. Speaker and gentlemen, the Supreme Court yesterday handed down a decision to the effect that if a person creates a trust of his property and provides that, during his lifetime, he shall enjoy the benefits of it, and when it is distributed after his death it goes to his heirs-the Supreme Court held that it goes to his heirs free of any estate tax.

Mr. SCHAFER of Wisconsin. This is a bill to tax the rich man. I shall not object.

....

Mr. SABATH. Reserving the right to object, all the resolution purports to do is to place a tax on these trusts that have been in vogue for the last few years for the purpose of evading the inheritance tax on the part of some of these rich estates?

Mr. HAWLEY. It provides that hereafter no such method shall be used to evade the tax.

Mr. SABATH. That is good legislation.

74 CoNG. REC. 7198 (1931), quoted in Byrum, 408 U.S. at 160 (White, J., dissenting). 
Congress refused to allow fundamentally testamentary lifetime gifts to evade estate tax. ${ }^{64}$ Ironically, state inheritance taxes were the source of the phrase "possession or enjoyment" of property in the federal estate tax statute; ${ }^{65}$ but, with the exception of Pennsylvania, states either have eliminated their inheritance tax or have restricted inclusion of lifetime transfers to those occurring within a limited time, such as within a year or a few years of the decedent's death. ${ }^{66}$

Because inter vivos transfers with retained donor control focus on the donor-decedent to determine when a gift is complete, the current transfer tax system seems to provide a more suitable means to prevent this type of abuse. While imperfect, ${ }^{67}$ the federal transfer taxes are more comprehensive, and hence more equitable, than most inheritance tax systems.

${ }^{64}$ See Estate of Church, 335 U.S. at 646 (citation omitted) (internal quotation marks omitted) ("Testamentary dispositions of an inter vivos nature cannot escape the force of this section by hiding behind legal niceties contained in devices and forms created by conveyancers.").

${ }^{65}$ Id. at 637-38 ("The 'possession or enjoyment' provision appearing in $\S 811$ (c) seems to have originated in a Pennsylvania inheritance tax law in $1826 \ldots$ Most of the states have included the Pennsylvania-originated 'possession or enjoyment' clause in death tax statutes, and with what appears to be complete unanimity, they have up to this day . . substantially agreed with this 1884 Pennsylvania Supreme Court interpretation.").

${ }^{66}$ See, e.g., supra notes $12,15,53$ and accompanying text.

${ }^{67}$ Section 2036, for example, should be amended to clarify that donor-retained corporate fiduciary powers, like donor-retained trustee powers, are subject to the statute. See DODGE, GERZOG \& CRAWFORD, supra note 1, at 393 (citations omitted) ("The majority opinion on the $\S 2036$ (a)(2) issue was based on the notion that the decedent's power was an 'administrative power' on account of the fact that it related to trust investments, and then stated that administrative powers lay outside of $\S \S 2036(a)(2)$ and 2038 , relying on a very early case (under a different statutory provision) that did not really come to grips with the issue, followed by the unsupported (and dubious) claim that estate planners had relied continuously on that case. Against the argument that the decedent effectively had retained the power to accumulate the trust income, the Court majority said that such power was constrained by a general fiduciary duty under corporate law. However, such a duty is as general as that which bounds the dispositive discretion of a trustee. The better argument would be that the Board of Directors, not the controlling shareholder, has control over dividend policy, and the Board would set dividend policy by considering the welfare of the corporation rather than according to the beneficial enjoyment of the trust."). 


\section{B. Rates}

A major tenet central to most inheritance taxes is the relevance of the decedent's blood or adopted relation to the beneficiary. ${ }^{68}$ Many countries

${ }^{68}$ See 2008 Jonnt COMmittee PrInt, 110Th CONG. 7-8, 18 (Comm. Print), available at https://www.jct.gov/publications.html?func=fileinfo \&id $=1318$.

Under the German inheritance tax, for example, the spouse is exempt from tax on the first $€ 307,000(\$ 471,429)$ received by gift or, subject to certain limitations, the first $€ 563,000(\$ 864,542)$ received by bequest. Each child is exempt from tax on the first $€ 205,000(\$ 314,798)$ received by gift. In the event of a transfer by bequest, this basic exemption amount is increased by an amount up to $€ 52,000(\$ 79,823)$ depending on the age of the child. Stepchildren, grandchildren, great-grandchildren, and, in the case of a bequest, parents and grandparents, are exempt from tax on the first $€ 51,200(\$ 78,595)$ received. Siblings, nieces, nephews, stepparents, sonsin-law, daughters-in-law, parents-in-law, divorced spouses, and, in the case of a gift, parents and grandparents, are exempt from tax on the first $€ 10,300(\$ 15,811)$ received. All others are exempt from tax on the first $€ 5,200(\$ 7,982)$ received.

...

Under most existing inheritance tax structures, a larger exemption and lower tax rate schedule is assigned to transfers to a surviving spouse, often followed by a smaller exemption and higher tax rate schedule for transfers to lineal descendents, followed by a yet smaller exemption and higher tax rate schedule for transfers to other relatives, followed by an even smaller exemption and higher tax rate schedule for other transfers. Consequently, in practice, the exemption levels and rate schedules favor retention of wealth within the nuclear family as opposed to a broad division of transferred wealth.

Id. Finland has three different rate schedules based on relationships to the transferor in its inheritance tax system. See id. at 8 . In its gift and inheritance regime, Spain likewise distinguishes tax brackets on a relationship basis but also incorporates a tax surcharge that varies based on relationship criteria and by the recipients pre-receipt level of wealth. See id. at 9 ; see also IOWA CODE $§ 450.10$ (1)-(2) (2014) (lineal tax rate $0 \%$, siblings and son-in-laws and daughter-in-laws' inheritance tax rates $5 \%-10 \%$, and collaterals' tax rates between $10 \%$ 15\%); KY. REV. STAT. ANN. \$ 140.070(1)-(2) (LexisNexis 2010) (lineal tax rate 2\%-10\% and collaterals' tax rate 4\%-16\%); MD. CODE ANN., TAX-GEN. $\S \S 7-203(\mathrm{~b})(2), 7-204$ (LexisNexis 2010) (lineal tax rate $0 \%$, sibling tax rate $0 \%$, and collaterals' tax rate $10 \%$ ); NEB. REv. STAT. $\$ \S 77-2004$, to -2006 (2013) (lineal and sibling tax rate $1 \%$ over $\$ 40,000$ exemption, remote relatives' rate $13 \%$ over $\$ 15,000$ exemption, and collaterals' tax rate $18 \%$ over $\$ 10,000$ exemption); N.J. REV. STAT. $\$ 54: 34-2$ (2014) (sibling tax rate $11 \%-16 \%$ depending upon amount of transfer, collateral tax rate $15 \%$ for amounts up to $\$ 700,000$ and $16 \%$ on amounts in excess of 700,000); 72 PA. CONS. STAT. ANN. $\S 9116$ (West $2000 \&$ Supp. 2013) (lineal tax rate $4.5 \%$, sibling tax rate $12 \%$, and collaterals' tax rate $15 \%$ ). Historically, the federal inheritance tax that existed at the turn of the nineteenth century imposed different rates depending on the familial relationship between the decedent and the beneficiary. See SURREY, MCDANIEL \& GUTMAN, supra note 2, at 3. 
and individual states allow preferred rates, ${ }^{69}$ or zero rates, ${ }^{70}$ for lineal descendents of the decedent. In those instances, the tax generates much less revenue because most decedents pass property to their children and grandchildren. ${ }^{71}$ Thus, more distant blood or adopted relatives are subject to higher rates, and nonrelative beneficiaries are generally accorded the very highest rates. ${ }^{72}$ A few systems include step-relatives somewhere in a preferred rate structure. ${ }^{73}$

Different rates based on relationships, however, make less sense than imposing different progressive rates based on the varying total amounts of property passing either from the decedent or to the beneficiaries. ${ }^{74}$ While. some states have progressive rates, those rates are usually applied after an exemption based on the familial relationship between the decedent and the beneficiary; other states have separate progressive rate structures depending

${ }^{69}$ See 2008 Jont Committee PrInt, 110 Th Cong. at 18.

${ }^{70}$ See, e. g., IOWA CODE $\S 450.9$ ("In computing the tax on the net estate, the entire amount of property, interest in property, and income passing to the surviving spouse, and parents, grandparents, great-grandparents, and other lineal ascendants, children including legally adopted children and biological children entitled to inherit under the laws of this state, stepchildren, and grandchildren, great-grandchildren, and other lineal descendants are exempt from tax."); see also Ky. REv. STAT. ANN. § 140.080(1)(c); MD. CODE ANN., TAX-GEN. § 7203(b)(2); N.J. REV. STAT. § 54:34-2(a)(2).

${ }^{71}$ See Kaplow, supra note 9, at 175.

${ }^{72}$ See supra note 68 and accompanying text.

73 See, e.g., IOWA CODE $§ 450.9$; KY. REV. STAT. ANN. § 140.070(1); see also N.J. REv. STAT. $\S 54: 34-2.1$. New Jersey also treats as a decedent-child relationship those mutually acknowledged relationships of at least 10 years duration, beginning at or prior to the child's fifteenth birthday. Although Indiana recently passed legislation to eliminate its inheritance tax, beginning January 1, 2013 retroactively, the Indiana provision had provided for stepchildren in its classification system. See IND. CODE ANN. § 6-4.1-1-3(a)(3) (LexisNexis 2007 \& Supp. 2011). For decedents dying after June 30, 2004 and before January 1, 2013, Indiana defined a Class A transferee as a "[s]tepchild of the transferor, whether or not the stepchild is adopted by the transferor." Id.

${ }^{74}$ Wealth distribution is logically affected by one's personal situation. Thus, telling a decedent without children that he would lose a tax benefit if he were to pass his or her property to a collateral relative or unrelated friend is both unreasonable and unkind; likewise, telling a decedent with a child that he or she would lose a tax benefit by passing his or her property to that child is unreasonable and unkind. Taxing a wealthy decedent on property passing at death at either progressive or high rates depending upon the size of his or her estate, regardless of his or her beneficiaries, is a much more reasonable, compassionate, and equitable way to raise revenue and to support public programs. 
on that relationship. ${ }^{75}$ Because decedents leave property to their loved ones, usually only fortuitous circumstances dictate whether those individuals are lineal descendents, more distant relatives, or nonrelations. ${ }^{76}$

\section{Exemptions for Specific Types of Property}

Some inheritance taxes exempt certain types of property, such as life insurance proceeds, from taxation. ${ }^{77}$ However, omitting a class of bequests

${ }^{75}$ See, e.g., IND. CODE Ann. § 6-4.1-3-10(b) (repealed 2013), available at www.in.gov/ legislative/ic/code/title6/ar4.1/ch3.html. Indiana's former law illustrates the complexity of such an elaborate structure:

With respect to a taxable transfer or transfers resulting from the death of a decedent who dies after December 31,2011, the first two hundred fifty thousand dollars $(\$ 250,000)$ of property interests transferred to a Class $\mathrm{A}$ transferee under the taxable transfer or transfers is exempt from the inheritance tax.

Id. However, a class $\mathrm{B}$ or class $\mathrm{C}$ beneficiary may exempt very little from the value decedent transferred to her: "The first five hundred dollars $(\$ 500)$ of property interests transferred to a Class B transferee under a taxable transfer or transfers is exempt from the inheritance tax."; and "[t] $]$ he first one hundred dollars $(\$ 100)$ of property interests transferred to a Class C transferee under a taxable transfer or transfers is exempt from the inheritance tax." IND. CODE ANN. $\S 6-4.1-3-11,-3-12$. Applying the appropriate exemption amount in Indiana, evidences a progressive rate structure; however, those rates are also dependent on the decedent's relationship with the beneficiary. See id. $\S 6-4.1-5-1($ b)-(c). Class A beneficiaries are taxed from $1 \%-10 \%$ marginal tax rates with the $10 \%$ bracket rate applying to net transfers over $\$ 1,500,000$ (that is, $\$ 92,250$, plus $10 \%$ of net taxable value over $\$ 1,500,000$ ). See id. $\S 6-4.1-5$ 1(b). Class B beneficiaries are taxed from 7\%-15\% marginal tax rates with the $15 \%$ rate applying to transfers over $\$ 1,000,000(\$ 107,000$, plus $15 \%$ of net taxable value over $\$ 1,000,000)$. See id. $\$ 6-4 \cdot 1-5-1$ (c). Class C beneficiaries are taxed from 10\%-20\% marginal tax rates with the $20 \%$ rate applying to transfers over $\$ 1,000,000$ ( $\$ 145,000$, plus $20 \%$ of net taxable value over $\$ 1,000,000)$. See id. $\$ 6-4.1-5-1(\mathrm{~d})$.

${ }^{76}$ See Estate of Odle v. Ind. Dep't of State Revenue, 991 N.E.2d 631 (Ind. T.C. 2013). Although the estate lost this case because its claim "was not adequately developed," the estate wanted the court to treat the beneficiaries as Class A rather than Class B or C beneficiaries (which they literally were under the state's inheritance statute) because Indiana's state constitution prohibited the legislature to "grant any title of nobility, nor confer hereditary distinctions." Id. at 633, n. 1 , quoting IND. CONST. art. $1, \S 35$. That is, the estate claimed a constitutional violation of Article 1 and Section 35 of Indiana's Constitution because the inheritance tax granted benefits to individuals based solely on birth distinctions. See id. at 632-33. In Odle, the decedent was a widower; he and his wife had no children. See $i d$. at 633 . The facts stated that this circumstance was the reason that he left his property "to several collateral relatives, including nephews, great nieces, and great nephews." Id. This common reason for not passing property to one's descendents inequitably, unreasonably, and unkindly, resulted in a heavier tax burden. See id.

${ }^{77}$ See, e.g., KY. REV. STAT. ANN. $\$ 140.030$ (2) ("The proceeds of an insurance policy payable to a designated beneficiary, including a testamentary or inter vivos trustee, other 
without an exceptional rationale is inefficient and inequitable. As such, exemptions should be granted sparingly and only when necessary to pursue another important policy goal. Yet, some inheritance taxes exempt various types of property without a sufficient rationale. ${ }^{78}$ Internationally, for example, while the exemption for household goods may make sense on simplicity grounds (especially if the total value is fairly insignificant), Germany's additional exemption for artwork, which is fairly complex and much more revenue-costly, may be more problematic. Moreover, exempting certain types of property from the tax may encourage tax avoidance. It allows the taxpayer to plan around such favoritism, which in turn may undermine other goals of the tax. ${ }^{79}$

Life insurance on the decedent's life is inherently testamentary, but some states like Maryland do not subject the proceeds to an inheritance tax, which in turn erodes the tax base and exaggerates inequalities. ${ }^{80}$ By contrast, two Code sections require the proceeds of life insurance on the

than the assured or his estate, shall be tax-free."); MD. CODE ANN., TAX-GEN. § 7-203(d) (LexisNexis 2010) ("The inheritance tax does not apply to the receipt of the proceeds of a life insurance policy payable to any beneficiary other than the estate of the insured."); N.J. REV. STAT. $\S 54: 34-4(\mathrm{c}),-4(\mathrm{f}),-4(\mathrm{~g})$. Ireland also exempts some life insurance proceeds from its gift and inheritance taxes. See 2008 JoINT COMMITTEE PRINT, 110TH CONG. 8 (Comm. Print), available at $\mathrm{https}: / / \mathrm{www} . j \mathrm{jct} . \mathrm{gov} /$ publications.html?func $=$ fileinfo\&id $=1318$.

${ }^{78}$ See, e.g., id. ("The German inheritance tax, for example, provides an exemption for household goods, works of art, and certain other property."). Germany, which partially (60\% or $85 \%$ ) or fully exempts artworks from its inheritance tax base, allows the heir to remain the owner. See STEPHAN SCHERER, THE HANDLING OF WORKS OF ART IN GERMAN INHERITANCE TAX LAW 1-2 (2011), available at $\mathrm{http}: / / \mathrm{www}$.sza.de/fileadmin/fm-dam/Mandanteninfor mationen/2011_Oct_N_Client_Information_German_Inheritance_Tax_Law.pdf. The sliding scale seems to depend on whether the artwork has significance, whether it remains in Germany or the European Union, whether the artwork is made available to the public to some extent, and whether the associated maintenance and preservation costs exceed any revenue produced. See id. The $100 \%$ exemption also requires that the owner own the piece or collection for at least 20 years. See id. Although art may be difficult to value, omitting those assets provides a large loophole in any tax system.

${ }^{79}$ For example, if life insurance proceeds are exempt in an inheritance tax system favoring lineal descendents, an estate planner might well suggest that a client with a collateral beneficiary name that collateral as an insurance beneficiary and pass nonexempt property to tax-favored relationship beneficiaries.

${ }^{80}$ Originally, life insurance proceeds were not included in a decedent's estate. Motivated by insurance companies advocating additional purchases of life insurance to evade the new estate tax, Congress specifically added insurance as subject to the tax in 1918. See SuRREY, MCDANIEl \& GUTMAN, supra note 2, at 524-25; see also DODGE, GERZOG \& CRAWFORD, supra note 1 , at 240. 
decedent's life to be included in his or her estate for estate tax purposes. ${ }^{81}$ The first provision requires the inclusion of insurance proceeds on the decedent's life either when the proceeds pass to the estate or when the decedent owned any of the incidents of ownership (that is, the economic benefits ${ }^{82}$ of the policy at death. ${ }^{83}$ The second provision requires inclusion if the decedent transferred the insurance or relinquished an incident of ownership within 3 years of death. ${ }^{84}$ Since 1981, however, insurance proceeds in an irrevocable life insurance trust (ILIT), which holds all of the ownership incidents, are exempt from estate tax under the plain language of the statutes. ${ }^{85}$ Thus, the current estate tax provisions should be amended to reverse that result as well.

${ }^{81}$ See I.R.C. $\$ \S 2042,2035$ (a). Section 2042 replaced section 811 (g) of the 1939 Code. In addition, section 2033 includes insurance owned by the decedent on another's life in the estate at its fair market value at decedent's date-of-death (generally at the interpolated terminal reserve value). See Treas. Reg. $\$ 20.2031-8$.

${ }^{82}$ See Treas. Reg. $\$ 20.2042-1$ (c)(2). Incidents of ownership are defined broadly in the regulations to include the economic benefits of the policy and powers such as the ability to change the policy's beneficiary or to obtain a loan against its cash-surrender value. Incidents of ownership also include a more than de minimis interest. See I.R.C. $\$ 2042$ (2) (exceeding "five percent of the value of the policy immediately before the death of the decedent"). The value of a reversionary interest is determined by utilizing the traditional methods of valuation like the actuarial tables. See id. When the decedent holds any of the incidents of ownership on insurance on his or her own life, the entire proceeds are includible in his or her gross estate. See Treas. Reg. $\S 20.2042-1$ (a)(3).

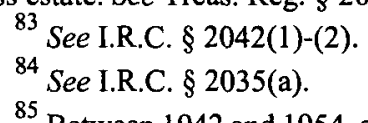

${ }^{85}$ Between 1942 and 1954, section 2042 required estate tax inclusion of life insurance on a decedent's life either because the decedent had owned the incidents of ownership in the policy or the decedent had paid the insurance premiums. However, in 1954, the premium payment test was abandoned to allow the decedent to avoid estate tax inclusion if the decedent had transferred all incidents of ownership more than 3 years before his or her death. See Dodge, Gerzog \& CraWford, supra note 1, at 240-41. Moreover, the payment of premiums within 3 years of death no longer affects inclusion of the proceeds under section 2035(a) because the "beamed transfer" of premium payments is no longer a basis for inclusion under that section as of 1981. See Estate of Headrick v. Comm'r, 93 T.C. 171 (1989), aff'd, 918 F.2d 1263 (6th Cir.1990), action on dec., 1991-012 (July 3, 1991); Estate of Leder v. Comm'r, 89 T.C. 235 (1987), aff'd, 893 F.2d 237 (10th Cir.1989). Thus, the sole incidents of ownership test paved the way for the viability of JLTTS--that is, the current literal language of section 2042 provides a loophole for the decedent's paid life insurance on his or her own life to escape estate taxation. See Headrick, 918 F.2d at 263. ILITs do not receive much criticism; that may be not only because of the strong insurance lobby but also because ILITs provide liquidity for an estate, which in turn means a quick source of funds for estate tax payments, pleasing all parties including the government. 


\section{Transfers to Charity}

In probably all tax systems, gifts to charities are fully or partially exempt from taxation. ${ }^{86}$ The benefits of the current transfer tax system include encouraging charitable gifts, both directly and indirectly. ${ }^{87}$ Some have pointed to the effect of charitable donations on the redistributive goal of the current transfer taxes. ${ }^{88}$ However, split-interest gifts that provide benefits for both charitable and noncharitable beneficiaries have been, ${ }^{89}$ and continue to be, ${ }^{90}$ the source of abuse in the estate tax area. A major strength of an inheritance tax is that, with a split-interest trust the noncharitable beneficiaries are taxed when their interests become possessory. This preferable tax treatment contrasts with the current transfer tax treatment of split-interest trusts that requires the use of the actuarial tables to value both the amounts of the charitable deduction and the noncharitable beneficiaries' interest at the time the property is transferred to the statutorily-defined splitinterest trust. Allowing actuarial value estimates to trump actual values received is a major flaw in the current transfer tax system. ${ }^{91}$

${ }^{86}$ See, e.g., I.R.C. $\S \S 170,2522,2055$ (income tax, gift tax, and estate tax); Batchelder, supra note 7 , at $81-82$. Because charities are tax exempt under the income tax system when a donor or a decedent transfers property to a charity, the recipient will have no taxable income. See Batchelder, supra note 7, at 81-82.

${ }^{87}$ See, e.g., Kaplow, supra note 9, at 185 ("Suffice it to say for present purposes that charitable giving is significant and may be greatly influenced by transfer taxation. Effects can also arise indirectly. For example, some oppose repeal or significant reduction of transfer taxation because the subsidy for charitable giving via exemption would thereby be eliminated.").

${ }^{88}$ See Aron-Dine, supra note 6, at 269 ("[T]here is evidence that the impact on charitable giving may be large. This is another issue worth bearing in mind in thinking about how wealth transfer taxes affect the distribution of resources in our society.").

${ }^{89}$ Prior to the 1969 legislation, requiring certain strict forms for split-interest gifts to charity, taxpayers routinely inflated their charitable deduction by overvaluing the interest purportedly passing to a charity and undervaluing the interest passing to the noncharitable beneficiary. See COMM. ON WAYS AND MEANS, TAX REFORM ACT OF 1969, H.R. REP. No. 91 413 , pt. 1, at 38-39 (1969); S. REP. No. 91-522, at 86-88 (1969).

${ }^{90}$ See generally Wendy C. Gerzog, From the Greedy to the Needy, 87 OR. L. REV. 1133 (2008); Wendy C. Gerzog, The Times They Are Not A-Changin': Reforming the Charitable Split-Interest Rules (Again), 85 CHI.-KENT L. REV. 849 (2010) [hereinafter Reforming Charitable Split-Interest Rules].

${ }^{91}$ See generally Gerzog, From the Greedy to the Needy, supra note 90; Reforming Charitable Split-Interest Rules, supra note 90. See also infra Part IV. 


\section{E. Transfers to Spouse}

Most inheritance tax systems allow unlimited transfers between spouses; ${ }^{92}$ some countries that do not recognize same-sex marriages also include transfers between domestic partners. ${ }^{93}$ Though not necessarily supported by the couple as "one person" theory" because couples differ in their property sharing arrangements, other reasons exist for allowing this exemption. ${ }^{95}$ Some relationships (especially those in a community property model) embrace the partnership theory of ownership for married couples, ${ }^{96}$

92 In 1981, Congress selected the marital unit as the unit of taxation for estate and gift taxes. See Economic Recovery Tax Act (ERTA) of 1981, Pub. L. No. 97-34, § 403(d)(1), 95 Stat. 172, 302-03 (codified as amended at I.R.C. 2056). The exemption is a deferral provision, requiring inclusion in the surviving spouse's estate. See, e.g., 72 PA. CoNs. STAT. ANN. $\S 9107$ (d) (West 2000 \& Supp. 2013) ("All succeeding interests which follow the interest of a surviving spouse in a trust or similar arrangement, to the extent specified in section 2113 , are transfers subject to tax as if the surviving spouse were the transferor.").

${ }^{93}$ See 2008 JonN COMMITTEE PRINT, 110Th CONG. 8 (Comm. Print), available at https://www.jct.gov/publications.html?func=fileinfo\&id=1318 ("In France, beginning August 22,2007 , inheritances between spouses and between unmarried individuals who live together and have entered into a partner contract are exempt from inheritance tax.").

${ }^{94}$ See, e.g., Estate and Gift Taxes: Hearing Before the H. Comm. on Ways and Means, 94th Cong. 1187 (1976) [hereinafter Statement of Charles M. Walker] (statement of Charles M. Walker, Assistant Secretary for Tax Policy, Dep't of Treasury); U.S. TREASURY DEP'T, GENERAL AND TECHNICAL EXPLANATION OF H.R. 3849, 97TH CONG., 1st SESS., reprinted in 8 Tax Management: Primary Sources, Series IV 39 (Tax Mgmt. Inc. ed., 1982); U.S. Treas. DeP'T, 91st Cong., TAX Reform Studies and Proposals (Comm. Print 1969), reprinted in RECOMMENDATIONS ADOPTED BY THE AMERICAN LAW INSTITUTE AT WASHINGTON, D.C. MAY 23-24, 1968 AND REPORTERS' STUDIES (1969) [hereinafter A.L.I. Recommendations]; Am. LAW InSt., Federal Estate and Gift TaXation: A.L.I. RECOMMENDATIONS, supra, at 258.

${ }^{95}$ Other justifications for the change to an unlimited marital deduction include removing problems involved in tracing interspousal transfers, aiding married couples with more modest estates, and simplifying the administration of the provision. See Statement of Charles M. Walker, supra note 94, at 1187-88; COMM. ON FDNANCE ECONOMIC RECOVERY TAX ACT OF 1981, S. REP. No. 97-144, at 127 (1981); COMM. ON WAYS AND MEANS, TAX INCENTIVE ACT OF 1981, H.R. REP. NO. 97-201, at 159 (1981); COMM. ON WAYS AND MEANS, ESTATE AND GIFT TAX REFORM ACT OF 1976, H.R. REP. No. 94-1380, at 17 (1976); STAFF OF J. COMM. ON TAXATION, 97TH CONG., GENERAL EXPLANATION OF THE ECONOMIC RECOVERY TAX ACT OF 1981, 233 (Comm. Print) ("Under prior law, it was often extremely difficult to determine the ownership of property held within the marital unit and to determine whose funds were used to acquire that property."); A.L.I. RECOMMENDATIONS, supra note 94, at 354.

${ }^{96}$ The partnership theory of marriage is the basis for community property statutes. See Bea Ann Smith, The Partnership Theory of Marriage: A Borrowed Solution Fails, 68 TEX. L. REV. 689, 697 (1990) ("Recognizing the economic risk that divorce poses to women and to mothers, states adopted the partnership concept specifically to increase the distribution of 
but the better explanation for most exemptions for spousal transfers is the practical difficulties in tracing a couple's property as the property is often intermingled or continually exchanged. ${ }^{97}$ One commentator has suggested, however, that the marital deduction may be unnecessary with an incomeinclusion or CIT approach because of the income tax date-of-death benefit of a potential basis step-up ${ }^{98}$ accorded to property received from a decedent. ${ }^{99}$

\section{The Comprehensive Inheritance TaX (CIT) Proposal}

In the CIT Proposal, Professor Batchelder suggests merging transfer taxes into the income tax system when gifts or bequests received by an individual aggregate to more than $\$ 1.9$ million. ${ }^{100}$ After that threshold, the donee's excess would be subject to income tax inclusion at a $15 \%$ surtax above the donee's income tax rate. ${ }^{101}$ Because each recipient has different economic means, Professor Batchelder concludes that taxing the donee more accurately reflects that person's ability to pay; likewise, she argues that the goal of imposing a $15 \%$ surtax on the highest income tax rate is to match the earned income rate, which requires including an additional tax to replicate the effect of the payroll tax. ${ }^{102}$ However, with respect to the estate tax, she contends that assessing the incidence of tax is difficult. ${ }^{103}$

Professor Batchelder criticizes the present transfer tax system as taxing inherited wealth less than earned income. She states that "[i]nherited wealth is currently taxed at one-fourth the rate of earned income due to high estate

property to women upon divorce and thus to offset the economic losses caused by divorce.") (citation omitted).

${ }^{97}$ See supra note 95 and accompanying text.

${ }^{98}$ See I.R.C. § 1014. Note, however, that the statute defines basis as the fair market value at a decedent's date-of-death or, if elected, the altemate valuation date. See id. Although most property appreciates and thus incurs a step-up in basis, when property loses value section 1014 requires a step-down in basis, which is disadvantageous to the recipient of the property.

${ }^{99}$ See David Joulfaian, Commentary, Replacing the Estate Tax with an Inheritance Tax: A Re-Examination, 63 TAx L. REV. 209, 210 (2009).

${ }^{100}$ See Batchelder, supra note 7, at 62.

101 See id.

${ }^{102}$ See id. at 2; see also 2008 Hearings on Alternatives, supra note 1, at 3 (statement of Professor Lily Batchelder) ("So in effect, extraordinary inheritances would then be taxed at the same rate that earned income is now taxed under the income and payroll tax.").

${ }^{103}$ See Batchelder, supra note 7, at 6; see also 2008 Hearings on Alternatives, supra note 1, at 3 (statement of Professor Lily Batchelder) ("In my view, its biggest weakness is that this relationship between, on one hand, the heir's financial circumstances, and on the other hand, the estate tax burden, is relatively imprecise."). 
tax exemptions and the exclusion of inheritances from the income and payroll tax bases." ${ }^{104}$ Although the current transfer tax may well under-tax wealth, any inheritance tax advocating a high exemption level per recipient is open to that same criticism. ${ }^{105}$ While the surtax results in a higher burden for those receipts above Professor Batchelder's exemption amount, ${ }^{106}$ Congress more easily could accomplish the same result by raising estate and gift tax rates or by lowering the exemption level. Also, the conversation cannot realistically be about wealth redistribution because only $22 \%$ of the recipients are not in the highest income tax bracket. For the majority of recipients, the CIT has no significant policy objective and may well decrease the taxation of wealth. ${ }^{107}$ Moreover, under the CIT, which advocates a $\$ 1.9$ million per donee exemption, ${ }^{108}$ family wealth concentration would persist. ${ }^{109}$

Some concerns about an inheritance tax with large exemptions, such as the CIT, are horizontal inequities ${ }^{110}$-particularly when identical businesses pass to different sized families. ${ }^{111}$ Related to that issue is whether the estate

${ }^{104}$ Batchelder, supra note 7 , at 2.

${ }^{105}$ See supra notes 21-24 and accompanying text.

${ }^{106}$ Professor Batchelder's surtax affects only those gifts and bequests that in the aggregate exceed her exemption amount. See supra note 102 and accompanying text.

${ }^{107}$ See infra notes 118-119 and accompanying text.

${ }^{108}$ See Batchelder, supra note 7, at 62-67.

${ }^{109}$ See Kopczuk, supra note 43, at 139 ("[T] here are stronger arguments for estate taxation to be made based on externalities from wealth concentration."). In her indictment of the tax burden unfairly taxing heirs, Professor Batchelder does not view family wealth as a concentrated unit. Indeed, her proposal is intended to "allocate burdens much more fairly at an individual level." Batchelder, supra note 7, at 69 . Because her paradigm emphasizes the inequitable tax burden of heirs and does not consider the unique relationship generally characteristic of closely related beneficiaries, Professor Batchelder does not attach value to family wealth remaining in the family. Nevertheless, it helps to know, after the decedent dies and passes wealth to his or her children, whether those children at some later time make gifts to each other when a sibling or other close relative is in need. Likewise, it helps to know whether and to what extent the decedent passes disproportionate bequests either to aid a less wealthy sibling or to pass more wealth to a more sensible sibling so that, either formally (through a legal instrument) or informally (by precatory request or moral implication), that sibling can assist another sibling who cannot handle a large amount of money.

${ }^{110}$ See, e.g., Hines, supra note 52, at 191.

111 See Udell, supra note 7, at 217 ("An inheritance tax, with a generous individual exemption can create significant horizontal equity distortions under these provisions for equal size businesses inherited by families of different sizes."). 
tax provisions beneficial to family farms and small businesses can and would be incorporated into an inheritance tax..$^{12}$

Additionally, inserting an inheritance tax into an income tax system (the payment vehicle for the CIT) may be less a solution for issues related to a recipient's ability to pay than a full-income inclusion approach with or without an additional independent transfer tax system. Allowing a large exemption for gifts and bequests makes an inheritance tax regime like the CIT proposal look more like the current estate and gift tax regime and less like the income tax system that is based on goals of fairness and ability to pay. Special exclusions and large exemptions make sense in a wealth transfer tax system, particularly for purchasing consumption items and exempting all but the wealthy from the tax. Contrary to ensuring the goal of horizontal equity in the income tax system, those large exemptions are unique and offensive to the treatment of other types of income. In an income tax system with the CIT, the CIT appears incongruent with much of the income tax provisions that are geared to ability-to-pay concepts. ${ }^{113}$ No other income tax provision ignores a windfall of $\$ 1.9$ million of income. ${ }^{114}$

112 See id.

${ }^{113}$ Professor Batchelder justifies the CIT exemption on two grounds:

On the one hand, its exemption protects a basic level of familial economic support that one hopes all parents will provide so that each child has a reasonable opportunity to grow and flourish. On the other hand, by gradually taxing inherited wealth in excess of this amount, a comprehensive inheritance tax encourages extraordinarily wealthy donors to share further wealth transfers with individuals who have fewer opportunities than their children.

Batchelder, supra note 7, at 3. First, while a large exemption is sensible in a transfer tax system, the income tax system currently provides for personal exemptions and the standard deduction in much more modest amounts that represent "a basic level of familial economic support." Id. Admittedly, those deductions pale in comparison to the $\$ 1.9$ million per-person lifetime exemption. Secondly, as already theorized, people will continue to leave their property to those relatively few people they love, and wealthy people generally name their wealthy family members and friends as their beneficiaries. See supra notes 6-7 and accompanying text. This pattern of giving would unlikely change. Those who want tax advantages already have the option of making charitable contributions to aid the poor; yet, most wealthy people contribute to their own charitable foundations, favorite museum, or alma maters. See Ken Stern, Why the Rich Don't Give To Charity, ATLANTIC (Mar. 20, 2013,9:50PM), http://www.theatlantic.com/ magazine/archive/2013/04/why-the-rich-dont-give/309254/.

114 The income tax exclusion sections do not aggregate to exceedingly large amounts of untaxed dollars. The de minimis fringe benefit, for example, underlines the income tax rejection of ignoring so large a benefit. See I.R.C. § 132(e); Treas. Reg. § 1.132-6(d)(1), $-6(d)(4),-6(e)(1)$. The only exception is, of course, the current exemption for gifts and 
Professor Batchelder's criticism about the under-taxation of inherited wealth supports a full income-inclusion approach for gifts and inherited wealth. In contrast to the CIT, a full-income inclusion system would be much simpler and more equitable. ${ }^{15}$

In 2009, under the then-current estate and gift tax system in effect when Professor Batchelder proposed the CIT, each donor could exempt a total of $\$ 1$ million in aggregate gifts and a total of $\$ 3.5$ million in total gifts and bequests. ${ }^{116}$ Also, generally wealth transfers are from parents to children. ${ }^{117}$ Thus, in 2009, the CIT would have produced additional revenue when a parent had one wealthy child, but a parent with two rich children would have received a total of $\$ 3.8$ million, rather than $\$ 3.5$ million, tax-free. A family with four children would have received $\$ 7.6$ million tax-free. ${ }^{118}$ If, as previously suggested, wealth redistribution means greater tax revenue that can be applied either to more spending or lower tax burdens for the less wealthy, the CIT is likely to result in less wealth redistribution than the current transfer tax system. ${ }^{119}$

The CIT also imposes complexity with its disparate and somewhat unusual $15 \%$ rate surcharge. ${ }^{120}$ Such additional taxes in the income tax

bequests under section 102; however, that section is rationalized at least in part because we have a transfer tax system.

${ }^{115}$ While more equitable, inclusion of gifts or bequests by focusing on the donees rather than the donor multiplies the practical difficulties of compliance. See supra note 46 and accompanying text; see also infra notes 126-129 and accompanying text. In 1894, the income tax statute taxed recipients on their gifts and inheritances; however, that treatment lasted only 1 year when the Supreme Court in Pollock v. Farmers 'Loan \& Trust Co., 157 U.S. 429, vacated on reargument, 158 U.S. 601 (1895), held that tax unconstitutional as a "direct tax." See SURREY, McDANIEL \& GUTMAN, supra note 2.

${ }^{116}$ See I.R.C. $\$ \S 2010,2505$; INTERNAL REVENUE SERVICE, Estate Tax, available at www.irs.gov/Businesses/Small-Businesses- \&-Self-Employed/Estate-Tax.

${ }^{117}$ See Kaplow, supra note 9, at 175 ("[M] ost gifts are to relatives, the largest being from parents to children.").

118 Assuming Congress in 2014-2015 is willing to increase exemption levels, aggregate family wealth would likely also increase under the CIT proposal as history has proved.

${ }^{119}$ Likewise, as Professor Hines emphasizes, the CIT may lack a GST tax, which in turn would result in more wealth concentration and lower tax revenue than the current transfer tax system. See Hines, supra note 52, at 203-04 ("The logic of inheritance taxation suggests removing the tax on generation-skipping transfers as part of a broader package of transfer tax reforms, but such a reform might have the paradoxical effect of promoting greater wealth concentration than that which would materialize in the absence of any wealth transfer taxes.").

${ }^{120}$ The unpopular bubble, subjecting estates between $\$ 10$ million and $\$ 17.184$ million to a federal surtax starting at $5 \%$ to the top rate of $55 \%$, effectively eliminated the benefits of the lower marginal rates applicable to the first $\$ 3$ million of property in an estate and the $\$ 1$ 
context are generally the result of penalties; the CIT surcharge adds complexity and does not fit well conceptually into that framework. ${ }^{121}$ In 2009 , the income tax maximum bracket was $35 \%$ while the maximum transfer tax rate was $45 \% .{ }^{122}$ Attaching a $15 \%$ surcharge to the $35 \%$ income tax rate would have subjected the excess to an additional $5 \%$ tax or to an income tax maximum rate of $50 \%$. That additional $5 \%$ rate, however, might well recoup some of the shortfall that the decedent would cause by leaving his wealth to more than one beneficiary.

As noted by other commentators, ${ }^{123}$ the CIT, like many state inheritance taxes, is dependent upon many of the current transfer tax concepts and terminology. ${ }^{124}$ By merging the transfer tax language into the income tax system and by focusing on the transferee rather than on the transferor, the CIT increases complexity for a greater number of taxpayers. To the extent that the effect falls on lower income taxpayers, whom Professor Batchelder aims to assist, the CIT would increase those taxpayers' tax return preparation costs. Similarly, the CIT would increase the burdensome

million exemption, until it was eliminated in the 2001 Act. See 2001 Act EXPLANATION, 110TH CONG., 57, 63-64 (Comm. Print 2003). The surtax intended to create an overall 55\% rate for those estates by imposing the surtax and taxing those amounts at $60 \%$. See id.; see also AUCUTT, supra note 39, at 6.

${ }^{121}$ See 2008 Hearings on Alternatives, supra note 1, at 77 (statement of Professor Joseph M. Dodge) ("An inheritance tax is basically like an estate and gift tax, but with a more complicated rate and exemption structure."). Professor Udell is cautious about the lack of a clear basis for integrating income and transfer taxes into a two-tier rate system:

The notion that the eventual wealth transfer tax rate should depend upon the particular income tax rate of the heir in the year that she receives an inheritance does not appear to be grounded in an argument that ties the two bases together. For example, it does not relate the wealth tax base to the income tax as, perhaps, a correction for income that is not measured well in the income tax.

Udell, supra note 7, at 216 . Udell envisions that through prearranging one's transaction, many estates would begin with a $0 \%$ rate before an inheritance tax rate is applied. Because it is not impossible to plan into losses that flow through a schedule $\mathrm{E}$ onto the form 1040 to achieve this result, the relationship between the estate and income tax bases will become important with a comprehensive inheritance tax.

Id. at 217 .

${ }^{122}$ See Rev. Proc. 2008-66, 2008-45 I.R.B. 1107, 1110 tbl.3 (2008).

${ }^{123}$ See Joulfaian, supra note 99 , at 212 ("More importantly, the proposed inheritance tax would not replace the estate tax. Its starting point is the division of bequests reported on the estate tax return."); supra note 17 , and accompanying text.

${ }^{124}$ See supra notes $17-19$. 
administrative duties and costs of executors. By contrast, very wealthy individuals deal with complex financial issues routinely. Although some wealthy taxpayers may urge the need for simplicity, they generally seek simplicity only when it results in their paying lower taxes. While, for example, taxing wealth without any valuation discounting is simpler, many wealthy taxpayers are fine creating complex transactions as long as the bottom line leaves them richer. ${ }^{125}$

Moreover, compliance issues riddle the CIT proposal. ${ }^{126}$ Accounting for gifts in an income tax system would be much more difficult than with the current estate and gift tax system in which virtually all of the applicable decedents' estate tax returns (currently less than 1\% of all estates) are examined ${ }^{127}$ and delinquent gift tax returns are often filed at the decedent's death. In 2012, the number of individual income tax returns filed was $182,332,000$; in that same year, 27,000 estate tax returns were filed-a ratio

${ }^{125}$ See, e.g., Estate of Walton v. Comm'r, 115 T.C. 589 (2000), acq., 2003-72, 2003-2 C.B. 964. The court invalidated then-Example 5 of Treas. Reg. $\S 25.2702-3(\mathrm{e})$, but also implicitly validated the taxpayer's use of short-term two-year zeroed-out grantor retained annuity trusts (GRATs), allowing the taxpayer to avoid the gift tax and to transfer additional value to family members transfer tax-free. See id. Family LLC's and FLPs, are also popular means by which the taxpayer reduces the value of liquid assets, typically from $30 \%$ to $70 \%$ by transferring those assets to family entities and then by transferring supposedly devalued entity interests to the younger members of the family. See DODGE, GERZOG \& CRAWFORD, supra note 1, at 452 . Taxpayers also use charitable lead annuity trusts (CLATs), by properly employing the actuarial tables to zero-out noncharitable family gifts. See id. at 460-61.

${ }^{126}$ See Kaplow, supra note 9, at 159, n.1 (citations omitted) ("Also, no attention is given to administrative concerns, especially pertaining to avoidance as well as the possibility that a transfer tax may in certain respects serve to backstop an income tax (although it can also reduce income tax receipts by heightening the benefits of schemes that reduce both taxes)."); see also Louis Kaplow, A Framework for Assessing Estate and Gift Taxation, in RETHINKING ESTATE AND GIFT TAXATION 164, 181, 186-90 (William G. Gale et al., eds., 2001).

${ }^{127}$ Because of personal liability risks, most executors of decedents' estates filing estate tax returns ask for and receive a closing letter from the Service before distributing the decedent's assets. See 31 U.S.C. $\$ 3713$ (2006). The 2012 rates of return examination for returns filed in 2011 were only $1.03 \%$ for individual income tax returns. See INTERNAL REVENUE SERVICE DATA BOOK, 2012, DeP'T OF TREASURY 26 tbl.9b (2013) [hereinafter IRS 2012 DATA BOOK] (applying data from October 1, 2011 to September 30, 2012); Frank Byrt, IRS 2011 Audit Rates Show Estate Tax Returns Under the Microscope, ACCOUNTINGWEB (Mar. 27, 2013), http://www.accountingweb.com/article/irs-201 1 -audit-rates-show-estatetax-returns-under-microscope/221442 ("Those estate returns with assets of $\$ 10$ million or more had an effective 116 percent rate of audit, as the IRS also examined returns in that category filed in prior tax years, in addition [to] those filed in 2011, and included them in the total fiscal year 2012 activity.") (applying the data from the IRS 2012 DATA BOOK). 
of approximately 6753 to $1 .{ }^{128}$ Reviewing all income tax returns to discover non-compliance with gifts would be a mammoth, and probably impossible, task. $^{129}$

Finally, any inheritance tax is dependent upon gathering information about the decedent's transfers. As stated by Joulfaian about the CIT, "It merely shifts the statutory incidence of the tax to the heirs while leaving in place all the existing complexities of deriving the size of the estate to be divided among the heirs."

A simpler solution to deal with the inequities that the CIT intends to cure is to reinstitute a more progressive rate system into the current transfer tax system. Because of the large exemption and because the rate tables have remained the same, transfer tax rates have been a flat rate of $45 \%$ between 2007 and 2009, of 35\% between 2010 and 2012, and, of $40 \%$ in 2013 and $2014 .{ }^{131}$ If the rates were changed to include multiple brackets so that those estates nearest to the exemption amount were, for example, taxed at a $35 \%$ rate, and rates were to progress to a top rate of $50 \%$, the impact on less rich

${ }^{128}$ See IRS 2012 DATA BoOK, supra note 127, at 4 tbl. 2.

${ }^{129}$ Recall the checkered history and continual compliance issues of taxing waiters' tip income in the restaurant industry, in which third parties and business records are common characteristics (unlike with family gratuitous transfers). See Food Industry Overview Accounting Principles, Information Systems, \& Industry Operating Procedures, IRS, available at $\mathrm{http}: / / \mathrm{www}$.irs.gov/Businesses/Food-Industry-Overview---Accounting-Principles,-Informa tion-Systems,-\&-Industry-Operating-Procedures (last updated Mar. 5, 2014) ("Four tip reporting programs are available for these taxpayers to enter into with the Service. Two of these pro forma documents are titled Tip Reporting Alternative Commitment (TRAC) and Tip Rate Determination Agreements (TRDA). The IRS developed the Employer Designed Tip Reporting Alternative Commitment (EmTRAC) Agreement program in response to employers in the food and beverage industry who expressed an interest in designing their own TRAC programs. Attributed Tip Income Program (ATIP) is a new three-year pilot program for food and beverage employers. The first annual basis begins January 1, 2007. Details and requirements for participation for employers and employees are available in Revenue Procedure 2006-30. The agreements serve a dual purpose: improving compliance of tipped employees and avoiding tip examinations. The TRAC agreement is by far the more popular with large and midsized taxpayers. It can be obtained at: www.irs.gov/Businesses/Small-Businesses-\&-Self-Employ ed/Voluntary-Compliance-Agreements---Restaurant-Tax-Tips."); Reporting Tip IncomeRestaurant Tax Tips, IRS, available at http://www.irs.gov/Businesses/Small-Businesses-\&Self-Employed/Reporting-Tip-Income-Restaurant-Tax-Tips (last updated Feb. 27, 2014); see also PUBLICATION 531: REPORTING TIP INCOME, IRS (2013), available at http://www.irs.gov/ publications/p531/ar02.html (advice on keeping a daily tip record).

130 Joulfaian, supra note 99 , at 212.

131 See American Taxpayer Relief Act of 2012, Pub. L. 112-240, 126 Stat. 2313, $\S 101$ (c)(1) (Jan. 2, 2013) (codified as amended at I.R.C. § 2001(c)); DODGE, GERZOG \& CRAWFORD, supra note 1, at 32-33. 
heirs would be reduced. This proposal is not equivalent to the impact of a CIT, which is better correlated with family size; ${ }^{132}$ however, it may correlate acceptably with lower income tax bracket beneficiaries.

The CIT proposal seeks to provide an incentive for the rich "to share further wealth transfers with individuals who have fewer opportunities than their children." ${ }^{, 133}$ Yet, few donors or decedents would alter the recipients of their noncharitable gift-giving in a statistically significant way. ${ }^{34}$ Most taxpayers with children give their assets to those children, ${ }^{135}$ that pattern is unlikely to change despite the tax benefits the CIT would promote. ${ }^{136}$ Moreover, there are more direct ways to encourage that behavior. For example, Congress could restrict charitable deductions to those programs of exempt organizations that predominantly aid the poor (feeding, clothing, providing scholarships, subsidizing educational programs, etc.), or could provide increased tax benefits for those particular charitable transfers. ${ }^{137}$

Professor Batchelder intends for the CIT to correct the poor public image of the estate tax as the "death tax," a term coined in a successful campaign launched by opponents "who have framed the estate tax as a double tax on frugal, hard-working donors who are ruthlessly taxed right at

${ }^{132}$ See Hines, supra note 52 at 190-91.

${ }^{133}$ Batchelder, supra note 7, at 3; see Ann Mumford, From Dahomey to London to DC: "Marketing" Wealth with the Proposal for a Comprehensive Inheritance Tax, 63 TAx L. REv. 221, 234 (2009). Mumford cites this incentive among others of the CIT's positive responses to the negative death tax hype: "The comprehensive inheritance tax includes a clear response to death tax imagery by targeting the behavior of the donor before death." Id.

${ }^{134}$ See Aron-Dine, supra note 6, at 266. Former policy analyst Ariva Aron-Dine is also skeptical of that result:

Realistically, it does not seem to me that the proposal will lead wealthy decedents to split their estates into, say, $\$ 500,000$ bequests to each of twenty needy, or even middle-income, people. Rather, what the proposal seems more likely to do is to encourage splitting large estates into $\$ 2$ million bequests to a somewhat larger number of reasonably well-off people.

Id.

${ }^{135}$ See Kaplow, supra note 9, at 175.

${ }^{136}$ See Richard Schmalbeck, Avoiding Federal Wealth Transfer Taxes, in RETHINKING ESTATE AND GIFT TAXATION, supra note 126, at 113,121-22 (concluding, persuasively, that even with the great tax benefit of the annual exclusion, few wealthy taxpayers currently are influenced to make those lifetime transfers because "the real barrier to full use of the annual exclusion is the strong preference of potential donors for the retention of economic power").

${ }^{137}$ See, for example, section $170(\mathrm{~b})$ which lists percentage limitations on the income tax charitable deduction for lifetime charitable gifts. 
the moment of death." 138 She intends the CIT to "improve public understanding of the taxation of wealth transfers." 139 But, a new spin is always in the wings to combat reasoned arguments. While the CIT focuses on the wealthy windfall recipients, it is not too much of a leap to believe that CIT opponents would frame the CIT in similar terms: that is, double taxation of those hard-earned dollars passing from a caring parent to his grieving loved ones. Instituting a new complex tax system is not the answer to powerful and contagious political rhetoric. Proponents need to develop a more effective message or to create a better counterspin.

Finally, one of the central reasons that makes the present estate tax preferable to an inheritance tax, including the CIT, is that the current transfer tax system deals well with inter vivos transfers with retained powers. Professor Batchelder states that the CIT would likely rely on the transfer tax definition of when a gift is complete. ${ }^{140}$ However, the giftcompletion rules differ in some important ways from the estate tax inclusion statutes so it is unclear what principles would apply. ${ }^{141}$ Current estate tax sections 2036 and 2038 anticipate and counter much potential abusive avoidance techniques involving retained control. ${ }^{142}$ Essentially, although they need reform, the current transfer taxes tax inherited wealth pretty well, determining what and when transfers should be taxed. While transfer tax reforms are needed, ${ }^{143}$ we would have more avoidance and abuse with either

138 Batchelder, supra note 7 , at 3.

${ }^{139}$ Id.

${ }^{140}$ See id. at 65 (emphasis added) ("Despite this fundamental change in the form of wealth transfer taxation, the proposal would continue to rely on much of the extensive body of laws, regulations, and guidance that have been developed under the U.S. estate tax system. For example, the existing rules governing when a transfer has occurred, how it is valued, and what transfers are taxable would remain unchanged. The proposal would not tax a large portion of wealth transfers, as under current law.").

${ }^{141}$ For example, the gift tax regulations consider a gift complete when a donor retains power to determine when the beneficiary will receive the property- "the manner or time of enjoyment"-but the estate tax statute would include property subject to such powers in the decedent's estate. Treas. Reg. § 25.2511-2(d); see also Lober v. United States, 346 U.S. 335 (1953). Likewise, the gift tax regulations incorporate the concept of a substantial adverse interest to allow a completed gift for joint powers despite the opposite estate tax rule stating that section 2038(a)(2) applies to joint powers regardless of a co-holder's substantial adverse interest. See Treas. Reg. \$ 5.251 1-2(e); see also Helvering v. City Bank Farmers Trust Co., 296 U.S. 85 (1935).

${ }^{142}$ See supra notes 55-66 and accompanying text.

${ }^{143}$ See Wendy C. Gerzog, From the Greedy to the Needy, supra note 90, at 1133; Wendy C. Gerzog, Not all Defined Value Clauses Are Equal, 10 PITT TAX REV. 1 (2012); 
an income-inclusion method or the CIT than we have now. Because each donee has different economic means, those advocating for an inheritance tax consider taxing the donee as more accurately reflecting ability to pay. ${ }^{144}$ However, because that integral part of an inheritance tax is also subject to abuse ${ }^{145}$ family attribution rules are one suggested option to include within a CIT or any other inheritance tax to deal with that issue. ${ }^{146}$

\section{BEHAVIOR}

Scholars have noted both a lack of consistent motives with respect to gifts in the current transfer tax system and a "substantial variation in behavior among estate taxpayers." 147 They have found more estate planning when a decedent had a long illness before his or her death, ${ }^{148}$ but even the very old do not often opt to divest themselves of their holdings. ${ }^{149}$ The data "provides support for the notion that there are important barriers to tax avoidance, perhaps related to the undesirability of giving up control over assets." ${ }^{150}$ In general, however, avoidance behavior is not predictable because of the differences among those subject to the estate tax — both different behaviors among wealthy individuals in general and different behaviors among wealthy individuals at various points in their lives.

Particularly for the wealthiest of those subject to transfer taxes, taxpayers are more unwilling to devolve themselves of their control of

Reforming Charitable Split-Interest Rules, supra note 90; Wendy C. Gerzog, Valuation Discounting Techniques: Terms Gone Awry, supra note 19, at 775; Kopczuk, supra note 43, at 154-55. This author has suggested reforms on such abusive estate planning devices as family limited partnerships and charitable lead annuity trusts.

${ }^{144}$ See 2008 Joint Committee Print, 110Th Cong. 19 (Comm. Print), available at https://www.jct.gov/publications.html?func=fileinfo $\&$ id $=1318$.

${ }^{145}$ See Udell, supra note 7, at 217 ("An inheritance tax, with a generous individual exemption can create significant horizontal equity distortions under these provisions for equal size businesses inherited by families of different sizes.").

${ }^{146}$ See 2008 JOINT COMMITTEE PrINT, 110TH CONG. at 23 n.70, citing Task Force on Federal Wealth Transfer Taxes, Report on Reform of Federal Wealth Transfer Taxes, A.B.A. $\S 17$, at 99-101 (2004).

${ }^{147}$ Kopczuk, supra note 43, at 157.

${ }^{148}$ See id. at 155-56.

${ }^{149}$ See id. at 156 ("[E]states are growing with age even among the very elderly, further underscoring that avoidance is not always pursued in advance.").

${ }^{150} \mathrm{Id}$. This finding about behavior also underlines the importance of sections 2036 and 2038 and their role in preventing erosion of the estate tax. 
assets than of their legal ownership those assets. ${ }^{151}$ While making annual exclusion gifts is an easy way to reduce a decedent's transfer tax liabilities, ${ }^{152}$ as Professor Schmalbeck has shown, the wealthy often do not make those gifts: "In the aggregate, it is estimated that, at most, only about 15 percent of the value of the annual exclusion gifts that could be made tax free from potentially taxable estates are in fact made." ${ }^{\text {153 }}$ His explanations for this underutilization include a work disincentive for young donees, retention of control over children's behavior and choices, and, for those close to the exemption amount, retention of sufficient assets to cover the taxpayer's own medical or other unanticipated lifetime needs. ${ }^{154}$

That last motivation was particularly evident in the fall of 2012 when estate planners, anticipating a possible return to 2001 Act sunset levels or at least a reduction of the currently available high exemption amounts, were urging their clients to take advantage of the $2012 \$ 5.12$ million per-person aggregate transfer tax exemption. ${ }^{155}$ The motives Professor Schmalbeck described may correlate with the experience of the recent economic downturn when assets declined sharply in value. That combination made even very wealthy taxpayers apprehensive that they would not have enough assets to sustain their desired standard of living. ${ }^{156}$ Statistics showed that " [ $\left.\mathrm{f}\right]$ ewer than 10 percent of clients with at least $\$ 10$ million have used even part of the exemption or plan to by December, said two-thirds of certified public accountants surveyed by the American Institute of CPAs."157

Professor Schmalbeck's rationale is meritorious in that much of what motivates behavior under the current transfer tax system is that most estate planning requires the donor to relinquish control of the transferred property,

${ }^{151}$ See Schmalbeck, supra note 136.

152 See id.

${ }^{153}$ Id. at 121 (citation omitted).

${ }^{154}$ See id.

${ }^{155}$ See Collins, supra note 54.

${ }^{156}$ See id.

${ }^{157}$ These figures were based on statistical information from financial planners and 227 accountants. See id. Polls dealing with charitable donations are another example of the wealthy's lower sensitivity to tax incentives. See Robert Frank, Why the Obama Tax Hikes Won't Kill Charity, WALL ST. J. BloG (Mar. 4, 2009, 3:28PM) blogs.wsj.com/wealth/2009/ 03/04/why-the-obama-tax-hikes-wont-kill-charity/ ("[Bank of America] and the Center on Philanthropy at Indiana University polled 700 households with net worths of at least \$1 million and incomes of $\$ 200,000$, which now counts as 'Obama rich.' ... So only $10 \%$ of the rich would cut off their contributions-and that is only if deductions went to zero. President Obama is proposing to reduce the deduction for top-income households to $28 \%$ from $35 \%$."). 
and that the wealthy prefer not to do that. ${ }^{158}$ Again, that is why sections 2036 and 2038 are so important to retain and that is one reason, besides inherently greater administrative ease and higher compliance levels, for retaining both the focus on the donor or the decedent and the current transfer tax system.

A former policy analyst at the Center on Budget and Policy Priorities, ${ }^{159}$ Aviva Aron-Dine argues that an annual wealth tax would discourage savings more than a wealth transfer tax that is imposed at the decedent's death. She bases that conclusion on the observation that "very rich people appear to accumulate wealth in large part because they want to be richer, rather than because they want to spend a lot of money or leave a lot of money to their children." 160

Moreover, some of the wealthy do opt for estate tax avoidance or reduction planning. While currently the majority of the wealthy divide their assets equally, ${ }^{161}$ whether they would continue to do so in a CIT system or whether they would change that pattern to create after-tax equal divisions is unclear; if the latter, David Joulfaian posits whether that would undermine the adoption of the CIT. ${ }^{162}$ Joulfaian also sees the potential for more bequests to foreign beneficiaries who would not be subject to the tax, concluding that fractional interest discounts would increase. ${ }^{163}$ Thus, he concludes that the effect of the CIT would likely be to multiply "opportunities for tax avoidance and noncompliance."164

${ }^{158}$ See also Kopczuk, supra note 43, at 154.

${ }^{159}$ See Aron-Dine, supra note 6, at 265 n.al.

${ }^{160} \mathrm{Id}$. at 268. Moreover, Aron-Dine agrees with Professor Batchelder's notion that transfer taxes should be a way of taxing nonmonetary advantages that wealthy parents transfer to their children in the form of, for example, employment or educational opportunities. See id. at 267 . Those benefits better correspond with a decedent's wealth than with the monetary inheritance of each of the decedent's children. See id.

${ }^{161}$ See Hines, supra note 52, at 191 ("As an empirical matter, even under estate taxation families generally divide their estates equally among surviving children.”).

${ }^{162}$ See Joulfaian, supra note 99 , at 211 . Joulfaian notes several behavioral changes in taxpayers' reactions to the enactments of the GST tax and the unlimited marital deduction. See id. at 211-12.

${ }^{163}$ See id. at 212 .

${ }^{164}$ Id. 


\section{What a FEDERAL INHERITANCE TAX OFFERS A TRANSFER TAX}

The primary benefit of an inheritance system is its timing of taxation upon receipt by the donee or beneficiary; such timing thereby eliminates the current reliance on actuarial tables ${ }^{165}$ to determine the value of a split interest in property such as a remainder interest. ${ }^{166}$ By matching the timing of the tax to the real transfer time, the inheritance system allows the tax consequences to reflect accurately the values of those gratuitous transfers. For example, the distortions and abuse of charitable split-interest trusts stem from the inherent flaws of valuing an interest by means of the actuarial tables at the time of the creation of the trust instead of when the charity or noncharitable beneficiary actually receives the property. ${ }^{167}$

The advantage of the actuarial tables is their simplicity and established acceptance. Yet, they do not and cannot reflect a real future value. No one has a crystal ball about future value, and the assumptions in the tables are inherently flawed. The actuarial tables assume a fixed rate of growth based on current interest rates, which at any time-but particularly when interest rates are low - are unlikely to be accurate in the long run. The tables rely on unreal assumptions, like the supposition that today's interest rate is relevant to the eventual payout of a particular investment, and they ignore the principal's actual growth during the term. Likewise, when an interest's duration is based on an individual's life instead of a term of years, the actuarial tables employ mortality assumptions that will often change during the term of the interest. ${ }^{168}$

Most pointedly, the taxpayer is the ultimate decisionmaker in choosing if and when to use an estate planning technique that employs the actuarial

${ }^{165}$ Annuities and other partial interests in property, such as remainders, must be valued by the actuarial tables. See I.R.C. $\S 7520$. Even before that statute's enactment in 1988 by section 5031(a) of Public Law 100-647, the regulations dealing with estate and gift tax valuation indicated their usage. See Treas. Reg. $\$ 20.2031-7$ (c) (indicating the applicable regulation and tables for valuing interests in a decedent's estate from before January 1,1952 to the present date); see also I.R.C. $\S 25.2512-7$ (c) (instructing a parallel valuation for gift tax purposes).

${ }^{166}$ See Batchelder, supra note 7, at 65 ("Rather than following the current approach, the proposal would apply an approach developed by William Andrews and wait to see who gets what before taxing transfers for which the taxable status of the beneficiary is unclear."); see also 2008 JoInt Committee Print, 110Th Cong. at 21-24 (Comm. Print), available at https://www.jct.gov/publications.html? func=fileinfo\&id=1318.

${ }^{167}$ See Reforming Charitable Split-Interest Rules, supra note 90, at 880-82.

${ }^{168}$ See Dodge, GERzog \& CRAWFORD, supra note 1, at 114-16. 
tables. Thus, while the actuarial tables may be theoretically neutral, they are in fact only used when their valuation assumptions are very likely to benefit the taxpayer. ${ }^{169}$

Thus, an inheritance tax system that taxes gratuitous transfers to a beneficiary on the actual receipt of the property does not need to rely on guesswork (that is, the actuarial tables) and therefore minimizes gaming in this area. At the same time, reforms of the current transfer tax system could curtail those abuses. ${ }^{170}$

\section{Conclusion}

Although an inheritance tax could ignore the relationship between a transferor and transferee, existing inheritance taxes base exemptions or rates on this feature. To that extent, existing inheritance systems inequitably tax the recipient based on the closeness of his or her relationship to the donor or decedent. Rewarding or punishing a relationship status between the transferor and transferee is neither a good measure of ability to pay nor an effective means of wealth redistribution.

Likewise, inheritance tax systems could tax lifetime gifts; however, those in the United States do not do so, and accordingly, lack the back-up of a gift tax. But, eliminating gifts from an inheritance tax favors the wealthiest of individuals who can best afford to make earlier-in-life transfers.

Most significantly, and characteristic of any inheritance tax or an income-inclusion model, is the focus on the recipient of a gratuitous transfer instead of on the transferor. Therefore, except when the transferor transfers all of his or her property to one individual, the major flaw in instituting a federal inheritance tax is its multiplication of individuals subject to the tax, which in turn magnifies administrative costs and decreases compliance rates. This escalation of returns results in a lifetime of unreported cash and untracked property transfers among family members. Taking a lesson from the unreported tip income of restaurant employees (both from its history of

${ }^{169}$ See 2008 Hearings on Alternatives, supra note 1, at 81 (statement of Professor Joseph M. Dodge) ("Actuarial tables are not only inaccurate in individual cases, but can be 'gamed' by such devices as GRATs and private annuities.").

${ }^{170}$ See Reforming Charitable Split-Interest Rules, supra note 90, at 880-82. While the goal of estate administration is to expeditiously settle the estate, the current transfer-tax system already employs limited recapture rules and long-term payment options that do not interfere with that aim. See, e.g., I.R.C. $\$ 2032 \mathrm{~A}$ (providing for recapture when, during the 10 years following a decedent's death, qualified heirs stop using the qualified real property for a qualified purpose like farming); I.R.C. $\S 6166$ (providing for the beneficial interest and estate tax installment-payment rules that cover a 15 -year period). 
abuse and complicated reporting requirements) a federal inheritance tax system would be virtually impossible to police, increase administrative complexity, and create a debacle of such large proportions that it would be even more hated than the current transfer tax system. Increasing the number of taxpayers subject to a death triggered tax would greatly undermine enforcement of such a tax.

Professor Batchelder's CIT proposal eliminates the disparity of burdens for some beneficiaries under the current transfer tax system. It also solves the problems of timing and valuation abuses that involve the actuarial tables. However, the CIT engenders its own problems: increased inequity (tax rates based on the lack of or more distant relationship between the donor or decedent and his or her beneficiary); increased family wealth concentration (families with more than one recipient having an increased total exemption); increased valuation abuse (increased fractional interest discounts); increased recordkeeping costs (including those taxpayers who cannot know whether they will reach and exceed the exemption level at some time in the future); increased compliance problems (due to the increased numbers subject to the tax); and increased complexity (relying heavily on, but sometimes changing, the current transfer tax terminology and principles, the CIT's rate surcharge, and its immersion into the federal income tax system).

Essentially, the transfer tax system works relatively well ${ }^{171}$ and has significant practical and theoretical advantages over a federal inheritance tax or a CIT.

${ }^{171}$ By means of its very large exemption (applicable exclusion amount), the transfer taxes collect revenue only from the property transfers of the very wealthiest of individuals. See 2008 Hearings on Alternatives, supra note 1, at 29-30 fig. 3 (statement of Professor Lily Batchelder) ("The estate tax system has been a small but stable source of revenue ever since the estate tax was enacted in 1916, generally raising between 1 and 2.5 percent of federal revenues as illustrated in Figure 3 ... . In 2007, the estate tax system raised about $\$ 26$ billion."). In 2008, $\$ 24,870,000$ was collected in estate taxes and $\$ 2,843,000$, in gift taxes. See STAFF OF J. COMM. ON TAXATION, MODELING THE FEDERAL REVENUE EFFECTS OF CHANGES IN ESTATE AND GIFT TAXATION, JCX-76-12, at 15-16 tbls.3-4(2012), available at https:/www.jct.gov/publications. html?func=startdown\&id=4492; Barnes, supra note 36; What's New-Estate and Gift Tax, supra note 40. 